Article

\title{
Phosphate Induced Arsenic Mobilization as a Potentially Effective In-Situ Remediation Technique-Preliminary Column Tests
}

\author{
Martin V. Maier ${ }^{1, *}$, Yvonne Wolter ${ }^{1}$, Daniel Zentler ${ }^{1}$, Christian Scholz $^{1}$, Charlotte N. Stirn $^{2}$ and \\ Margot Isenbeck-Schröter ${ }^{1}$ \\ 1 Institute of Earth Sciences, Ruprecht-Karls-University Heidelberg, 69120 Heidelberg, Germany \\ 2 Institute of Geography, Ruprecht-Karls-University Heidelberg, 69120 Heidelberg, Germany \\ * Correspondence: martin.maier@geow.uni-heidelberg.de; Tel.: +49-6221-546-004
}

Received: 28 September 2019; Accepted: 5 November 2019; Published: 12 November 2019

\begin{abstract}
Arsenic (As) contamination of groundwater is commonly remediated by pump and treat. However, this technique is difficult to apply or maintain efficiently because the mobility of arsenic varies depending on the geochemical aquifer conditions. Arsenic interacting with the sediment can cause strong retardation, which is counteracted by ions competing for sedimentary sorption sites like silica, bicarbonate and phosphate. Phosphate competes most effectively with arsenic for sorption sites due to its chemical similarity. To accelerate an ongoing but ineffective pump and treat remediation, we examined the competitive effect of increasing phosphate doses on contaminated aquifer material of different depths and thus under distinct geochemical conditions. In the columns with phosphate addition, significant amounts of arsenic were released rapidly under oxic and anoxic conditions. In all tests, the grade of leaching was higher under anoxic conditions than under oxic conditions. As(III) was the dominant species, in particular during the first release peaks and the anoxic tests. Higher amounts of phosphate did not trigger the arsenic release further and led to a shift of arsenic species. We suggest that the competitive surface complexation is the major process of arsenic release especially when higher amounts of phosphate are used. Commonly arsenic release is described at iron reducing conditions. In contrast, we observed that a change in prevailing redox potential towards manganese reducing conditions in the oxic tests and iron reducing conditions in the anoxic column took place later and thus independently of arsenic release. The reduction of $\mathrm{As}(\mathrm{V})$ to $\mathrm{As}(\mathrm{III})$ under both redox conditions is presumed to be an effect of microbial detoxification. A loss of sulphate in all columns with phosphate indicates an increased microbial activity, which might play a significant role in the process of arsenic release. Preliminary tests with sediment material from a contaminated site showed that phosphate additions did not change the $\mathrm{pH}$ value significantly. Therefore, a release of other metals is not likely. Our results indicate that in-situ application of phosphate amendments to arsenic-contaminated sites could accelerate and enhance arsenic mobility to improve the efficiency of pump and treat remediation without negative side effects. The novelty of this approach is the use of only small amounts of phosphate in order to stimulate microbial activity in addition to surface complexation. Therefore, this method might become an innovative and cost-effective remediation for arsenic contaminated sites.
\end{abstract}

Keywords: arsenic; phosphate; competitive surface complexes; release; mobility; remediation

\section{Introduction}

Remediating arsenic (As) contamination is challenging and generally pump and treat technology is applied. For this method, water is extracted from the contaminated aquifer and treated on-site to 
reduce the contamination from the source area and to avoid the contaminant from spreading. Iron(II) sulphate and iron(II) chloride are commonly used as reactants to treat the extracted water (e.g., [1,2]). The effectiveness of this approach is often limited due to the geochemistry of the remediation site. In addition, a continuous input of energy is required. If the treatment is inefficient or even terminated because of decreasing efficiency, the contaminant remains.

Aquifer properties like redox conditions and mineral composition are the main factors controlling arsenic reactions and thus mobility, which can differ considerably from site to site [3,4]. Under neutral conditions there are two redox species of inorganic arsenic-Arsenite $\left(\mathrm{H}_{3} \mathrm{AsO}_{3}\right)$, where arsenic is in the trivalent oxidation state $\mathrm{As}(\mathrm{III})$ and Arsenate $\left(\mathrm{HAsO}_{4}{ }^{2-}\right.$ and $\left.\mathrm{H}_{2} \mathrm{AsO}_{4}{ }^{-}\right)$in the pentavalent oxidation state $\mathrm{As}(\mathrm{V})$. Under oxic conditions $\mathrm{As}(\mathrm{V})$ is the dominant redox state. $\mathrm{As}(\mathrm{V})$ is less mobile than $\mathrm{As}(\mathrm{III})$ because it forms complexes on mineral surfaces, especially on hydroxides and oxides of iron(III) [5-7] as well as on calcite [8]. Under iron reducing conditions arsenic is released from those surfaces into groundwater and remains mobile after subsequent reduction to As(III) $[4,9,10]$. In contrast to this, arsenic precipitates as sulphide or forms sulphide complexes if sulphate-reducing conditions prevail and sulphate is available [11,12].

Instead of water extraction, more recent remediation strategies aim to mobilize or immobilize arsenic within the aquifer [13]. In remediation practice, different amendments are used in-situ to decrease arsenic mobility by creating a suitable redox milieu for the sorption of arsenic on iron minerals or the precipitation of iron sulphide minerals [14-20]. However, through immobilization, the contaminant remains in the subsoil and a remobilization cannot be ruled out. A different approach is to increase arsenic mobility by implementing iron reducing conditions in combination with a hydraulic barrier (e.g., pump and treat) to remove the contaminant [21,22]. Artificially implemented iron reducing conditions (e.g., with lactate) are difficult to maintain stable during the entire remediation process and undesired impacts on the aquifer's geochemistry, such as heavy metal release, are a possible side effect.

Phosphate is an opponent substance for arsenate in building up strong surface complexes on iron(hydr-)oxides [23-25]. In $\mathrm{pH}$ neutral conditions, the affinity of phosphate to form surface complexes on iron minerals like goethite and gibbsite phases is higher than the one of $\mathrm{As}(\mathrm{V})[26,27]$. Recent studies indicate similar processes with calcite, although the sorption of arsenic on calcite is less favoured than onto iron minerals [28]. It may become a relevant reaction when the proportion of iron minerals in the aquifer sediment is low or if hydrogen carbonate dominates. The reaction kinetics are discussed controversially. Some studies assume an incorporation of arsenic into calcite [29], while others show that arsenic is bound in surface complexation $[8,30]$. Results of both studies agree that predominantly the $\mathrm{As}(\mathrm{V})$-species interacts with calcite, which can be replaced by phosphate.

Arsenic release from sediment by phosphate addition has been topic to research since the early 70 s and recent studies show that the high complexity of the process limits the predictability for field application [31-33]. One study found that high phosphate dosages up to $300 \mathrm{mM}$ to sediment samples under oxic conditions led to arsenic release rates of $80 \%$ [33]. Neither longer reaction nor repeated treatment could significantly increase the arsenic leaching. A different study demonstrated that pulse injections of phosphate could increase the total desorption of arsenic up to $94 \%$ [34]. Even low phosphate amendments of $6 \mathrm{mM}$ could rapidly desorb more than $35 \%$ of the total arsenic from the sediment and continuing amendments led to up to $65 \%$ desorption [35].

The novelty of the approach presented here is an increase of arsenic mobility without changing the aquifer's geochemistry for future field application [36,37]. Phosphate is known to compete with arsenate for sedimentary sorption sites but so far there is no information about the effect of different amounts of phosphate on the mobility of arsenic under different redox conditions. In order to investigate the driving processes, we conducted column tests with amendment of varying phosphate concentrations under oxic and anoxic conditions and closely monitored arsenic species distribution in the sediment and the column outflow. In contrast to previous studies [34,35], low phosphate concentrations were used to identify the relevant mechanisms underlying arsenic mobility 
and speciation. This preliminary laboratory study is the basis for further research to develop an innovative and more efficient remediation field method.

\section{Materials and Methods}

\subsection{Aquifer Material, Groundwater Sampling and Analysis}

The aquifer sediment material was collected during previous investigations at the contaminated site in Lampertheim, Germany [36]. Sediments were gathered through percussion drilling with polyethylene-lined probes $(\mathrm{d}=100 \mathrm{~mm} ; \mathrm{l}=1 \mathrm{~m})$ to the aquifer basis $(30 \mathrm{~m}$ b.g.l.). The liners were sealed immediately after recovery to avoid changes of the predominant redox milieu in the aquifer. The cores were opened lengthwise under argon atmosphere for sediment profile description and sampling for geochemical analyses. The cores were covered with plastic wrap and stored at $-18{ }^{\circ} \mathrm{C}$. For the column tests, these cores were defrosted and prepared under argon atmosphere. Sediments from the partially water-saturated ( 5 to $6 \mathrm{~m}$ ) and completely water-saturated (11 to $12 \mathrm{~m}$ ) depths of the aquifer were used to ensure they contain the redox-adapted microfauna.

Sedimentary characteristics like grain size, moisture content, smell and colour were determined according to standard regulations (ISO 14688). For the analytical procedures and the column preparation the sediment was homogenized under argon atmosphere. Analytical procedures were performed in replicate to ensure reproducibility. Chemicals used were of per analysis (p.a.) quality. Aqua regia extractions were done once before and once after the column tests and with the sediment standard BAM U112a. Therefore, $1 \mathrm{~g}$ of moist sample was mixed with $3 \mathrm{~mL}$ of nitric acid $\left(65 \% \mathrm{HNO}_{3}\right.$ p.a., J.T. Baker) and $9 \mathrm{~mL}$ of hydrochloric acid $(37 \% \mathrm{HCl}$ p.a., J.T. Baker), covered with watch glasses and simmered for about $3 \mathrm{~h}$ at about $130{ }^{\circ} \mathrm{C}$ (method modified after ISO11466:1995). After cooling, the samples were filled up to $50 \mathrm{~mL}$ with distilled water, filtered through a pleated paper filter and stored at $4{ }^{\circ} \mathrm{C}$ until measurement.

In order to distinguish how the different arsenic species are bound to the sediment surfaces, fractionated elutions - based on the method by Reference [38] — were made before and after the column tests. Under argon atmosphere $3.5 \mathrm{~g}$ of moist sediment was weighed into four vessels respectively. Distilled water $(40 \mathrm{~mL})$ was added to two of the samples and $40 \mathrm{~mL}$ of $1 \mathrm{M}$ sodium dihydrogen phosphate $\left(\mathrm{NaH}_{2} \mathrm{PO}_{4} \cdot \mathrm{H}_{2} \mathrm{O}\right.$ p.a., Grüssing $)$ to the other two. The closed samples were stirred for $24 \mathrm{~h}$ on a shaking table, centrifuged ( $5 \mathrm{~min}$ at $4000 \mathrm{rpm}$ ) and then filtrated through $0.45 \mu \mathrm{m}$ membrane filters. The samples were acidified with $6 \mathrm{M}$ hydrochloric acid to $\mathrm{pH} 1$ and stored at $4{ }^{\circ} \mathrm{C}$ until measurement.

Stratified groundwater samples from the study site were taken based on the regulations of ISO 5667-11:2009 with a Grundfos MP1 (Grundfos GmbH, Erkrath, Germany) and a packer system after 30 min of pumping. Temperature (SenTix ${ }^{\circledR}$ 940, WTW, Weilheim, Germany), oxygen (CellOx ${ }^{\circledR} 325$, WTW, Weilheim, Germany), electrical conductivity (Tetracon ${ }^{\circledR}$ 925, WTW, Weilheim, Germany), pH value (SenTix ${ }^{\circledR}$ 940, WTW, Weilheim, Germany) and redox potential (SenTix ${ }^{\circledR}$ ORP-T 900, WTW, Weilheim, Germany), were measured in a flow cell with a WTW Multiline (Multi 3420, WTW, Weilheim, Germany). Results are presented in Table A1. Samples for cations, anions and carbon species were filtered with $0.45 \mu \mathrm{m}$ syringe membrane filters and cation samples stabilized with $\mathrm{HNO}_{3}$, arsenic samples with $6 \mathrm{M} \mathrm{HCl}$ (p.a. Fluka) to $\mathrm{pH} 1$.

Water cation samples (groundwater and column outflow) and the extractions/elutions from the sediment samples were measured with an ICP-OES (VISTA-MPX CCD Simultaneous, Varian/Agilent, Mulgrave, Australia) for $\mathrm{As}, \mathrm{Fe}, \mathrm{Mn}, \mathrm{Ca}, \mathrm{Mg}, \mathrm{K}$ and $\mathrm{Na}$ after standard-procedures and calibrated with element standards (Ultra Scientific), the ICP multi-element standard solution IV (Merck) and validated with two reference materials (SPW-SW2 and TMDA-51.3). The calculated error of the measurement was between 1 and $15 \%$. Arsenic species were measured with a flow-injection hybrid generating system (FI-HG) coupled to the ICP-OES according to Reference [39]. Species were determined in two measurement steps as described in [40] and with a subsequent iterative calculation of arsenic. Water anion samples were analysed with ion chromatography (Dionex DX-120, ThermoFisher Scientific, 
Sunnyvale, $\mathrm{CA}$, USA) for $\mathrm{Cl}, \mathrm{Br}, \mathrm{NO}_{3}, \mathrm{SO}_{4}$ and $\mathrm{F}$ with an AS9 $\mathrm{HC}$ column and standard calibration for the measured elements (Merck). Total carbon (TC) and inorganic carbon (IC) of the groundwater were measured with a TOC- $\mathrm{V}_{\mathrm{CPH}}$ (Shimadzu, Kyoto, Japan), from which the total organic carbon (TOC) content was calculated. A total inorganic carbon standard (Ultra Scientific) was used for calibration. Phosphate concentrations from the column outflow were determined with the molybdenum blue method and measured at $880 \mathrm{~nm}$ with a photometer (Specord 50, Analytik Jena, Jena, Germany). Total carbon of sediment samples was determined with a sulphur/carbon analyser (Leco SC 144DR, San Joseph, MI, USA). Measurement limits, used reference materials and standard deviations are given in Table A2.

The geochemical conditions in the columns were deduced from hydrogeochemical water composition with respect to redox-sensitive and $\mathrm{pH}$-sensitive parameters like iron, manganese and bicarbonate (Table A1). Because the aquifer material at the study site is carbonate-dominated, the system is sufficiently buffered and measurements of $\mathrm{pH}$ values at the column outflow were hence omitted. Redox conditions can be inferred more accurately from the prevailing geochemistry than from redox measurements. Overall measurement quality and methodological errors were evaluated through calibrations and standards, which are presented in Table A2. Ion balance calculations after [41] were within acceptable limits ( $10 \%$ deviation) for the samples without phosphate addition.

\subsection{Column Tests}

All columns were designed identically with exception of the column diameters. The columns were filled under argon atmosphere with the sandy aquifer material from the contaminated site. For the oxic columns, sediments of 5 to $6 \mathrm{~m}$ depth were used, which was within the groundwater fluctuation zone and represents oxic to suboxic conditions. For the anoxic columns, sediments from below the groundwater table in 11 to $12 \mathrm{~m}$ depth were taken, representing anoxic conditions (Table A3). Glass wool at both ends of the columns allowed an even flow inside the columns. Top and bottom were sealed airtight with a screw top containing an outlet pipe. The columns were oriented vertically and connected to a peristaltic pump (Minipuls 2, Gilson, Middleton, WI, USA) to obtain a constant upward oriented flow (Figure A1). Through sodium bromide tracer tests the hydrodynamic properties were determined in each column after the leaching tests. Therefore, a $20 \mathrm{mg} / \mathrm{L}$ concentration of tracer was added continuously to the test water for $44 \mathrm{~h}$. Samples were taken every $30 \mathrm{~min}$ and measured with IC (Dionex DX-120, ThermoFischer Scientific, Sunnyvale, CA, USA) and a WTW multiline (bromide probe Br 500 and electrical conductivity, both WTW, Weilheim, Germany) respectively. The hydrodynamic dispersivities and effective porosities were calculated from breakthrough curves for each column using a one-dimensional analytical solution of the transport equation after Kinzelbach (1987), which was implemented in an Excel worksheet model [42,43].

Chemical analyses of the groundwater at the research site showed predominantly earth alkaline to alkaline water with high contents of hydrogen carbonate. For the column tests replicated groundwater with a composition according to the groundwater in the corresponding depth of the aquifer was prepared every four days and the ingredients (Table A4) were dissolved by carbon dioxide addition with a soda machine. For the anoxic columns, the process-water was degassed with argon for four days before application in order to remove oxygen.

The flow discharge varied from 180 to $220 \mathrm{~mL} /$ day respectively, depending on the column diameter. Flow rates were adapted correspondingly to 1 and 1.2 pore volumes (PV) per day to ensure comparable flushing of both columns. Accordingly, the effective porosity of the column fillings was 25 to $30 \%$ as calculated from the tracer test.

The experimental conditions of each column are shown in Table A5. All tests were initially run with replicated groundwater without phosphate for eight pore volumes. The anoxic columns were operated strictly anoxic in an argon-filled glove box. Tests with phosphate amendment were done in duplicate (columns 2, 3 and 5, 6, results of duplicates shown in Figures A3 and A4) to consider random errors. Reference columns (column 1 and 4 ) were run without phosphate amendments. 
The timing of phosphate increments depended on the observed arsenic release. Deviations from the scheduled values were caused by phosphate precipitation in the storage vessels. Influent and effluent water was sampled daily to determine the actual concentration of the reactant and to calculate balances.

A fraction collector was used for sampling of columns 1,2, 4 and 5 and a collective daily sample was taken for columns 3 and 6 . The applied analytical methods and sample preparation are listed in Table A6 and described in Section 2.1.

\section{Results}

\subsection{Oxic Tests}

In the oxic tests without phosphate addition, (column 1, Figure 1a) the initial concentration of arsenic was about $300 \mu \mathrm{g} / \mathrm{L}$ and decreased quickly to level off at approximately $50 \mu \mathrm{g} / \mathrm{L}$. At the beginning of the test, As(III) was the dominating species. After $20 \mathrm{PV}$ the shares of As(V) gradually increased while As(III) decreased. By the end of the experiment (PV 44), As(V) was the only remaining species. In total $0.67 \mathrm{mg}$ of arsenic was released from the column.
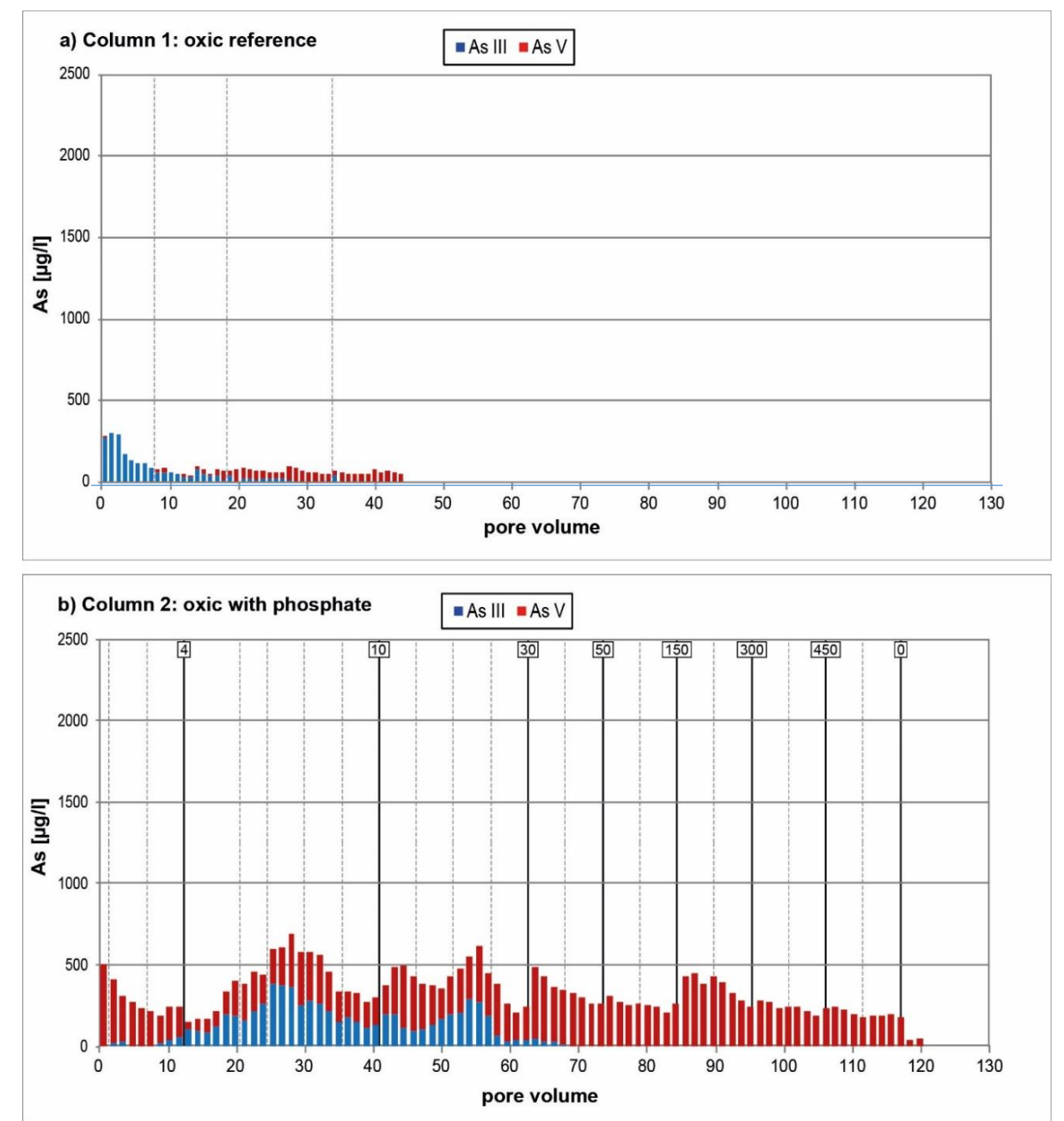

Figure 1. Arsenic release during the oxic column test, (a) column 1 without phosphate addition and (b) column 2 with phosphate addition (duplicate column 3 in Figure A2c). Vertical lines indicate refilling of replicated groundwater and the scheduled phosphate concentration $(\mathrm{mg} / \mathrm{L})$.

In the oxic tests with phosphate amendments (columns 2 and 3) concentrations of around $500 \mu \mathrm{g} / \mathrm{L}$ arsenic were desorbed at the beginning, which was predominantly $\mathrm{As}(\mathrm{V})$ (Figures $1 \mathrm{~b}$ and $\mathrm{A} 2 \mathrm{c}$ ) and 
declined to about $300 \mu \mathrm{g} / \mathrm{L}$ at the end of the test. The first addition of phosphate $(4 \mathrm{mg} / \mathrm{L})$ led to a rapid release with concentrations up to $690 \mu \mathrm{g} / \mathrm{L}$ and $820 \mu \mathrm{g} / \mathrm{L}$ arsenic respectively, more than $50 \%$ As(III). With every phosphate amendment of increased concentration, a peak in arsenic release was observed, independently of the amended phosphate concentration. After 50 PV As(V) became the dominant species and remained the only species until the end of the test. In columns 2 and 3 the arsenic concentration of the outflow decreased to $35 \mu \mathrm{g} / \mathrm{L}$ by the end of the experiment. In total $4.69 \mathrm{mg}$ and $4.37 \mathrm{mg}$ arsenic were released from columns 2 and 3 respectively (Table 1 ).

Table 1. Arsenic contents in mg in aqua regia extractions of the sediment before and after the column tests in comparison with the cumulative release measured from the column outflow.

\begin{tabular}{ccccccc}
\hline Column Test & $\mathbf{1}$ & $\mathbf{2}$ & $\mathbf{3}$ & $\mathbf{4}$ & $\mathbf{5}$ & $\mathbf{6}$ \\
\hline Cumulative outflow release $(\mathrm{mg})$ & $0.67 *$ & 4.69 & 4.37 & 3.20 & 11.4 & 13.1 \\
Sedimentary As before test $(\mathrm{mg})$ & & \multicolumn{2}{c}{$17 \pm 5$} & & \multicolumn{2}{c}{$25 \pm 0.8$} \\
Sedimentary As after test $(\mathrm{mg})$ & & $12.1 \pm 2.8$ & $11.4 \pm 3.8$ & & $15.5 \pm 3.3$ & $12.9 \pm 2.6$ \\
\hline Sedimentary mass losses $(\mathrm{mg})$ & & $4.9 \pm 7.8$ & $5.6 \pm 8.8$ & & $9.5 \pm 4.1$ & $12.1 \pm 3.4$ \\
\hline
\end{tabular}

* Shorter duration of test.

Aqua regia extractions before and after the column test show a sedimentary loss of arsenic similar to the cumulative release during the test, which corresponds to a total arsenic decrease of $26.5 \%$. Accordingly, the arsenic release of columns 2 and 3 with phosphate amendment was six times higher than in the reference column 1 without phosphate addition. Of the added phosphate, 93 to $97 \%$ could be retrieved in total from the column outflow.

In the oxic column, the first arsenic release peak is observed together with high manganese concentrations. Nitrate was not detectable, iron and sulphate remain low (Figures 2 and A3) and manganese returns to low levels after $55 \mathrm{PV}$, while arsenic release is continuously observed in accordance with phosphate amendments (Figure 2).

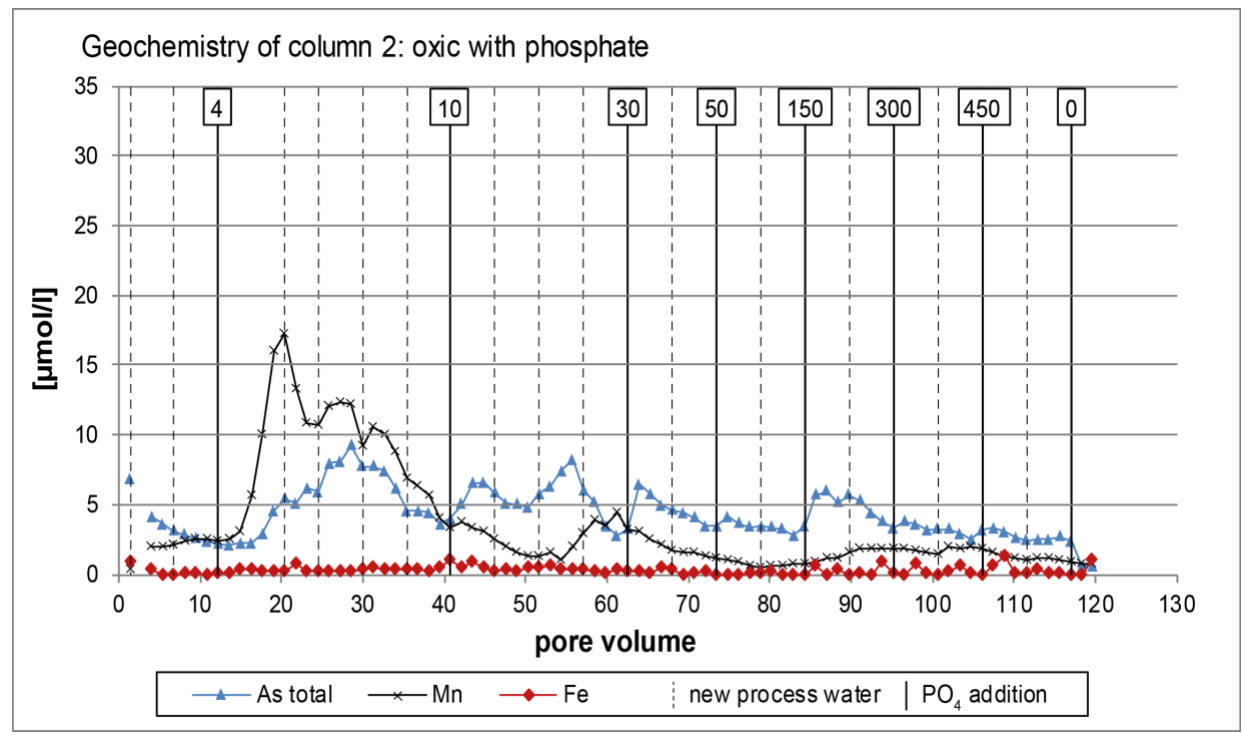

Figure 2. Release of arsenic, manganese and iron in the oxic column 2. Arsenic release is independent from geochemical milieu conditions, although it is temporarily accompanied with elevated manganese.

\subsection{Anoxic Tests}

In the anoxic column without phosphate addition (column 4, Figure 3a) the initial concentration of arsenic in the outflow was around $200 \mu \mathrm{g} / \mathrm{L}$ and increased to about $300 \mu \mathrm{g} / \mathrm{L}$ during the test. After 
10 PV the species distribution shifted from predominantly As(V) in the beginning to almost exclusively As(III), which remained the main species until the end of the test. A total of $3.20 \mathrm{mg}$ arsenic was released from the column.
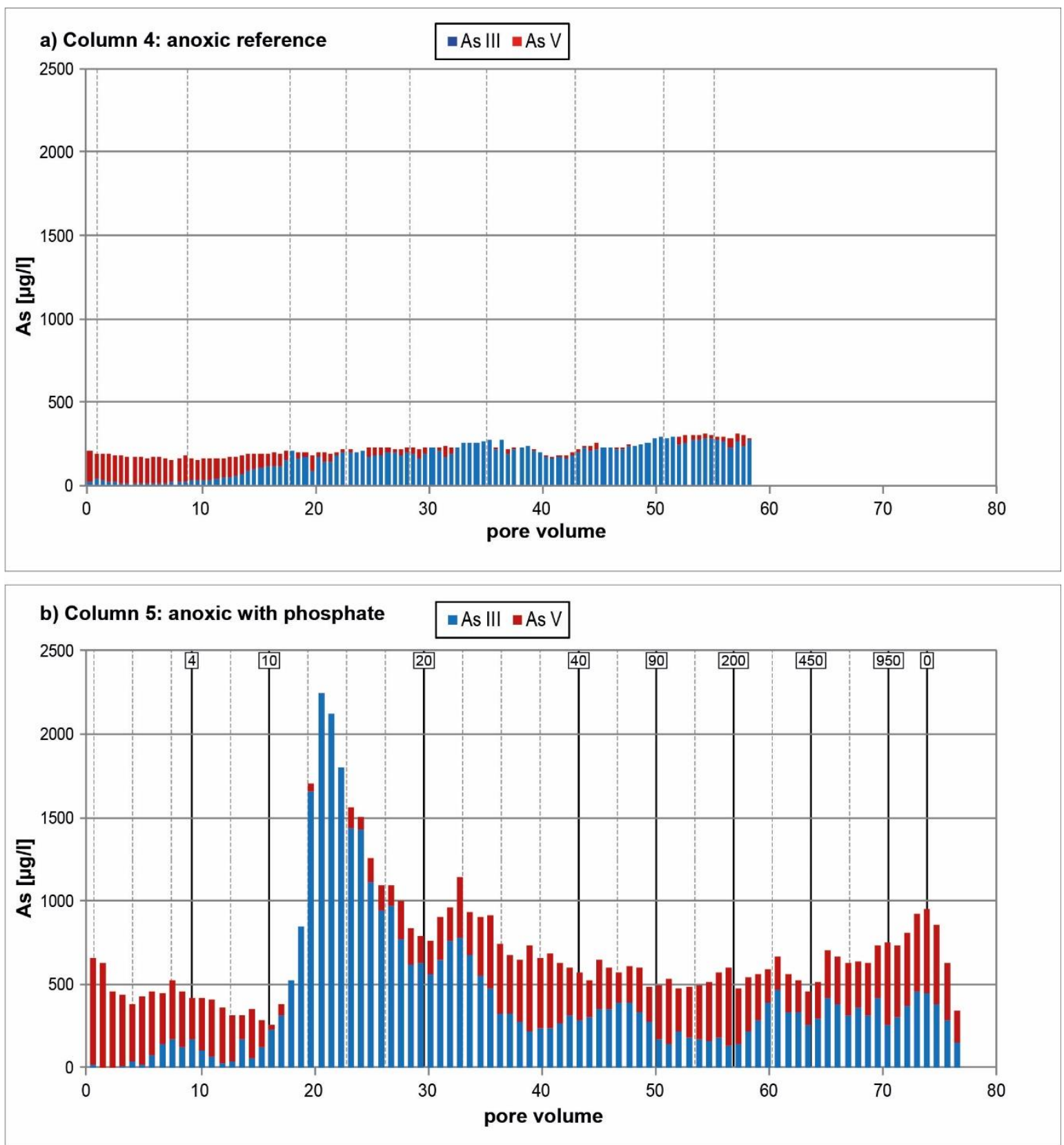

Figure 3. Arsenic release during the anoxic column tests, (a) column 4 without phosphate addition and (b) column 5 with phosphate addition. Vertical lines indicate refilling of replicated groundwater and the scheduled phosphate concentration $(\mathrm{mg} / \mathrm{L})$.

Both anoxic columns 5 and 6 (Figures $3 \mathrm{~b}$ and $\mathrm{A} 4 \mathrm{c}$ ) at the beginning show an arsenic release of around $600 \mu \mathrm{g} / \mathrm{L}$, which is predominantly As(V). About $10 \mathrm{PV}$ after the addition of $10 \mathrm{mg} / \mathrm{L}$ phosphate, the arsenic release increased significantly up to $2251 \mu \mathrm{g} / \mathrm{L}$ and decreased again immediately. Every increase in added phosphate concentration was followed by an arsenic release peak. The amplitudes of the following peaks were lower than the first mobilization peak, even with very high phosphate dosages. According to the release balances, most of the extractable arsenic was mobilized during the first two peaks. 
The species distribution in both anoxic columns with phosphate amendment shows a similar pattern. Differences are caused by heterogeneities of the sediment like variations in arsenic concentrations and organic compounds. With the onset of the first peak the species distribution changed from initially predominantly $\mathrm{As}(\mathrm{V})$ towards almost exclusively $\mathrm{As}(\mathrm{III})$. In column 5 the shares of $\mathrm{As}(\mathrm{V})$ increased again after $30 \mathrm{PV}$ and from $42 \mathrm{PV}$ until at the end the distribution of both species stayed equal. In contrast, As(III) remains the dominating species in column 6 after the first release peak. The high release concentrations of arsenic correlated with high shares of As(III) in both anoxic columns.

Total arsenic amounts of $11.4 \mathrm{mg}$ (column 5) and $13.1 \mathrm{mg}$ (column 6) were released during the anoxic tests (Table 1). According to a sediment concentration of $25 \mathrm{mg} / \mathrm{kg}$ (aqua regia extraction) before the test, $44-52 \%$ of the total arsenic content was released from the columns, which was validated by the aqua regia extractions after the column tests.

Through the phosphate amendment the arsenic release could be accelerated significantly and enhanced by four times on average in comparison to the reference. $85 \%$ of the amended phosphate was retrieved at the column outflow.

In the anoxic columns ( 5 and 6 ) the onset of iron reducing conditions were observed after $30 \mathrm{PV}$ and thus after the main arsenic peak (Figures 4 and A4). Strongly iron reducing conditions with high iron concentrations in the outflowing water did not correlate with high arsenic concentrations. Sulphate concentrations showed no change with time but from the added sulphate in the process water up to $7.72 \%$ was consumed in the column (Table A7). The constant $\mathrm{HCO}_{3}$ concentrations in the column outflow indicate stable $\mathrm{pH}$ values as detected in preliminary studies (Figure A5). Manganese increased slightly throughout the test after phosphate amendments.

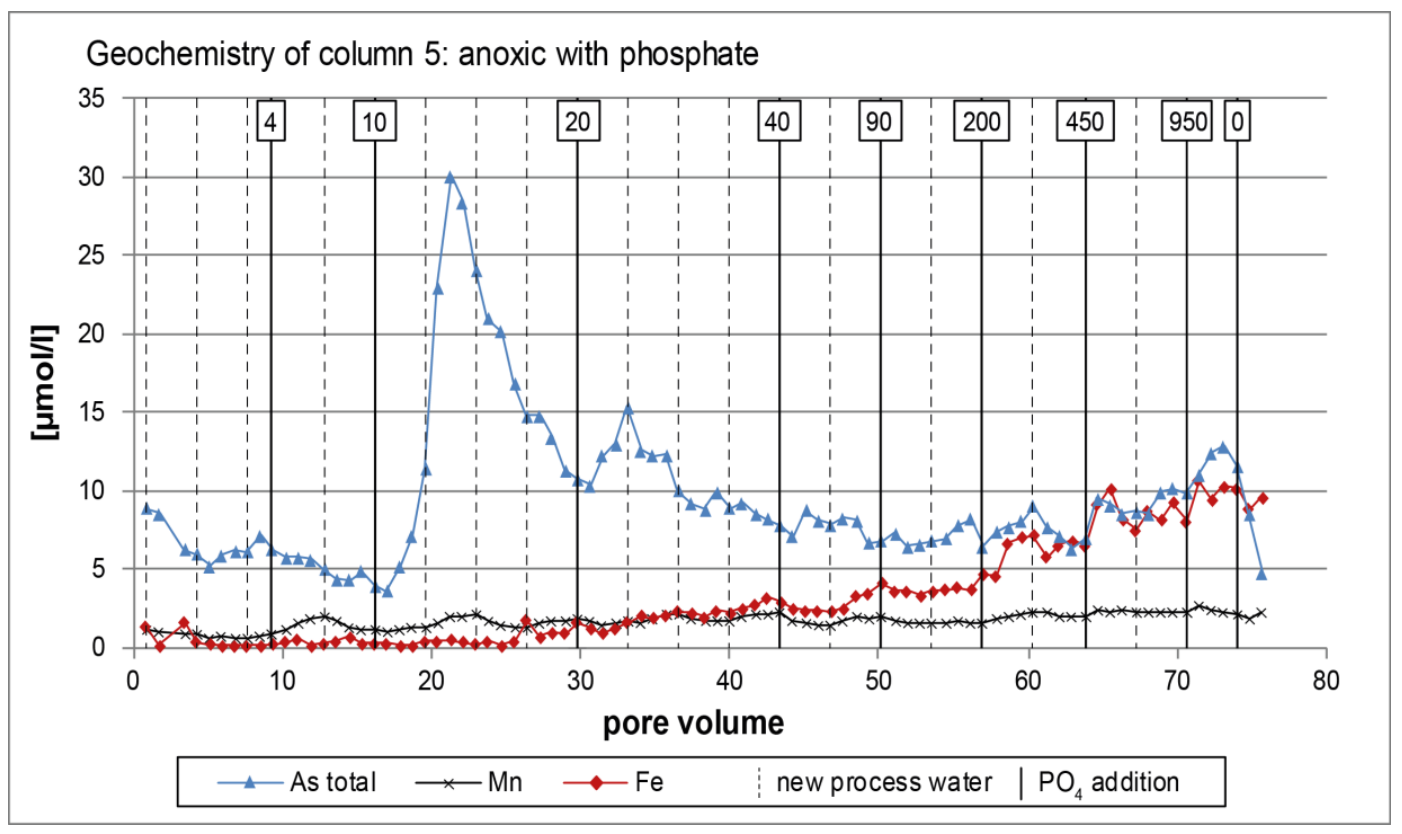

Figure 4. Release of arsenic, manganese and iron in the anoxic column 5. Manganese increases steadily while iron remains low and increases right after the high arsenic release peak.

\section{Discussion}

In all columns with phosphate amendment a significant release of arsenic was observed from the beginning during low phosphate amendment concentrations. Even smaller amounts of phosphate than used in other studies ( $0.04 \mathrm{mM}$ instead of $6 \mathrm{mM}$ ) led to a comparable amount of arsenic release [35]. Phosphate concentrations measured from the column outflow demonstrate that most of the added phosphate was neither adsorbed or precipitated in the columns nor consumed by microorganisms.

As expected the total arsenic release rates were higher and faster under anoxic conditions. However, in comparison to the reference the release rates in columns 2 and 3 with phosphate were 
significantly increased under oxic conditions. Consequently, the addition of phosphate increased microbial processes, which consumed oxygen and nitrate, temporarily causing manganese-reducing conditions. This observed manganese release occurred simultaneously with a small peak of arsenic. Groundwater composition does not indicate a further development of suboxic conditions after the manganese peak but rather a return to more oxic conditions with low iron, low manganese and predominantly $\mathrm{As}(\mathrm{V})$. In the anoxic columns with phosphate (columns 5 and 6), the released arsenic contains high shares of both arsenic species compared to the reference (column 4). This shows that phosphate amendment significantly increased the normal arsenic desorption process under anoxic conditions. High mobility of $\mathrm{As}(\mathrm{V})$ can be attributed to competitive surface complexation with phosphate under both applied conditions, while the pattern of arsenic species might be attributed to microbial processes. The increased arsenic release is independent of the prevailing redox conditions and no significant effect on the $\mathrm{pH}$ value was observed (Figure A5).

Accelerated microbial activity in the columns with phosphate addition is indicated by the loss of sulphate (Table A7) and the increased iron and manganese in the column outflow. In both reference columns without phosphate, the sulphate concentration remained stable and no significant amounts of iron or manganese were released (Figure A6).

At a neutral $\mathrm{pH}$ value, the release of other metals besides arsenic is not probable. Before the field application of this approach at other sites without high carbonate buffering the possibility of heavy metal release should be tested. The aquifer material of the study area contained no other metals besides arsenic, thus the effect of phosphate amendments on other metals could not be considered.

Variations between the cumulative outflow and the sedimentary mass balances are caused by the different methodological approaches and the standard deviation of sedimentary arsenic measurements (Table 2). In the column outflows with phosphate amendment the arsenic release is 3.5 to 4.5 times higher under oxic and anoxic conditions. Compared to the phosphate extractable fractions in Table 2, a total of $36 \%$ (oxic) to $65 \%$ (anoxic) arsenic was released, most of it already with low additions of phosphate. The significant shift of arsenic species under anoxic conditions from $\mathrm{As}(\mathrm{V})$ to $\mathrm{As}(\mathrm{III})$ in the column outflow indicates enhanced microbial arsenic reduction in the column, as in the phosphate elution most of the extractable and thus surface bound arsenic was $\mathrm{As}(\mathrm{V})$.

Table 2. Arsenic species distribution in the sediment elutions and the release measured from the column outflow.

\begin{tabular}{lcccccc}
\hline \multirow{2}{*}{ Column } & \multicolumn{2}{c}{$\begin{array}{c}\text { Water Extractable } \\
\text { Arsenic (mg) }\end{array}$} & \multicolumn{2}{c}{$\begin{array}{c}\text { Phosphate (1 M) Extractable } \\
\text { Arsenic (mg) }\end{array}$} & \multicolumn{2}{c}{$\begin{array}{c}\text { Arsenic Released from } \\
\text { Column (mg) }\end{array}$} \\
\cline { 2 - 7 } & As(III) & As(V) & As(III) & As(V) & As(III) & As(V) \\
\hline $\mathbf{2}$ (oxic) & 0.13 & 1.24 & 1.19 & 11.9 & 1.13 & 3.58 \\
\hline $\mathbf{5}$ (anoxic) & 0.20 & 2.24 & 1.48 & 16.3 & 6.78 & 4.60 \\
\hline
\end{tabular}

The first phosphate amendments with low concentrations $(10 \mathrm{mg} / \mathrm{L})$ triggered a strong $\mathrm{As}(\mathrm{III})$ release. After this first peak, $\mathrm{As}(\mathrm{V})$ shares increased with respect to redox conditions. These findings indicate that a complex interplay of microbial processes and surface complexation govern the distribution of arsenic species depending on the availability of phosphate (Figure 5).

Preliminary tests indicated that under all described conditions a supersaturated phosphate concentration is necessary to start the release process [36]. The column tests in this study show that rapid release already starts at relatively low phosphate concentrations of $4 \mathrm{mg} / \mathrm{L}(0.04 \mathrm{mM})$ and continues when concentrations are increased during time. The wide range of phosphate amendment concentrations used in the other published studies illustrate that processes not only rely on the concentration of phosphate but are also strongly linked to the geochemistry of the sediment matrix, the water composition and microbial activity. 


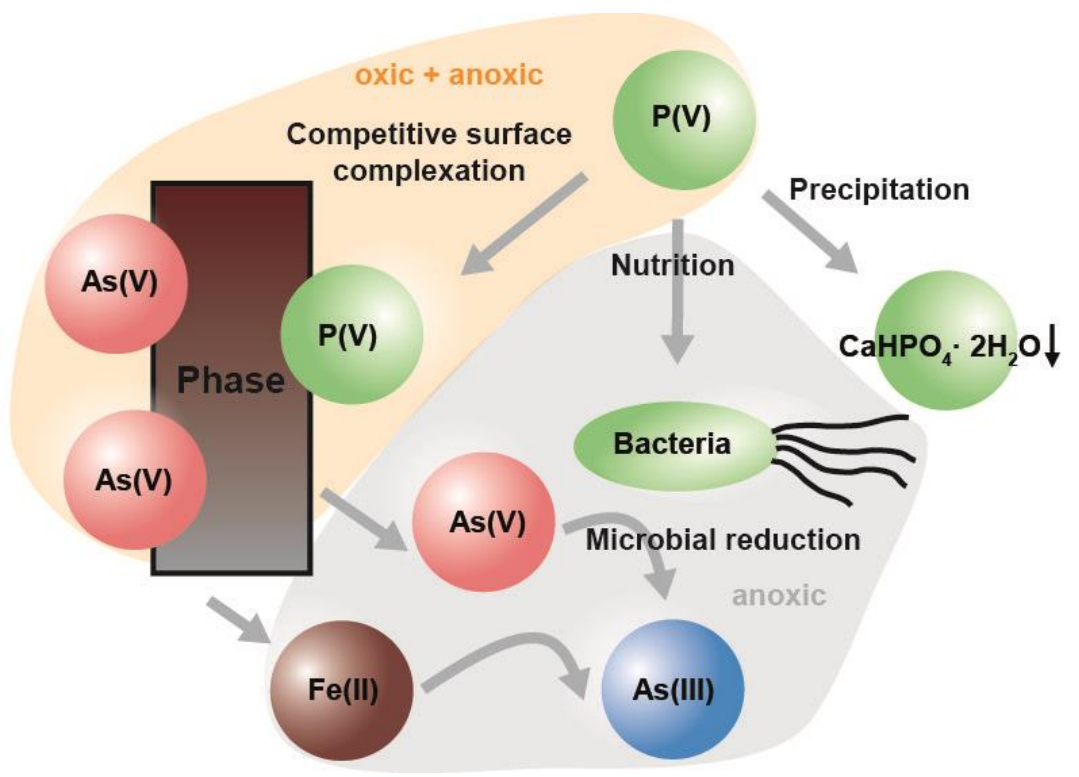

Figure 5. Schematic sketch of dominating processes supported by the results of this study: arsenic release by competitive surface complexation on iron and calcite minerals (phase), reduction of $\mathrm{As}(\mathrm{V})$ to $\mathrm{As}(\mathrm{III})$ by $\mathrm{Fe}(\mathrm{II})$ or arsenic-reducing bacteria and phosphate precipitation mainly as brushit $\left(\mathrm{CaHPO}_{4} \cdot 2 \mathrm{H}_{2} \mathrm{O}\right)$.

During the oxic tests, iron and manganese were not observed in significant concentrations in the column output, whereas nitrate reduction could be detected, which indicates that microbial activity in the columns leads to suboxic conditions. The temporal shift towards As(III) in the oxic tests with phosphate amendment might be artefacts of anoxic conditions in the sediment used for the columns or the fraction of As(III) on the sediment matrix (Table 2) but are more likely the effects of microbial processes fuelled by phosphate addition. Also, the high shares of As(III) in the anoxic tests were not linked to significant increases of manganese or iron. This is quite surprising considering the current standard of knowledge that microbial arsenic reduction prevails under iron-reducing conditions.

The observed rapid reduction of $\mathrm{As}(\mathrm{V})$ to $\mathrm{As}(\mathrm{III})$ after the $10 \mathrm{mg} / \mathrm{L}$ phosphate amendment could be explained by the stimulation of arsenic-reducing microorganisms by phosphate, which is likely the limiting factor for biological activity in the observed case. Macur et al. (2004) support the hypothesis that microorganisms are capable to oxidize and to reduce arsenic coexist in natural sediments [44]. Both tests indicate that the microorganisms were present in the sediment and just needed a time of incubation to grow in population. Campbell et al. (2006) subdivided two pathways of microbial As(V) reduction, the respiratory pathway and the detoxification [45]. Under anoxic conditions, the respiratory pathway was the dominating process. According to scientific consensus the As(V) reduction to As(III) by microbial respiration processes comes along with reducing conditions. For example, Huang et al. (2011) and Dhar et al. (2011) identified a microbe that mediated $\mathrm{As}(\mathrm{V})$ reduction under iron reducing conditions $[46,47]$. They agree with Zhang et al. (2009) that microbial desorption and iron reduction occur independently [48].

During our oxic and anoxic tests the $\mathrm{As}(\mathrm{V})$ release and subsequent reduction to $\mathrm{As}(\mathrm{III})$ was found independently from iron reducing conditions, which could be explained with the competitive surface complexation by phosphate from iron or carbonate surfaces. Another reason could be the dissolution of arsenic-bearing carbonates [28,30]. We suggest that the arsenic reduction of $\mathrm{As}(\mathrm{V})$ to $\mathrm{As}(\mathrm{III})$ is mainly due to microbial detoxification and is thus decoupled from the redox condition. The increased availability of phosphate leads to accelerated microbial activity combined with the uptake of $\mathrm{As}(\mathrm{V})$ in competition with phosphate and the release of As(III) species after the detoxification process.

In addition, Slaugther et al. (2012) demonstrated that arsenate reduction is suppressed at phosphate concentrations $>0.5 \mathrm{mM}$ and even inhibited at high $\mathrm{P} / \mathrm{As}$ ratios [49]. This observation gives 
a reasonable explanation for the decrease of these microbial detoxification processes with increasing phosphate amendments and a shift of arsenic species from dominantly $\mathrm{As}$ (III) to As(V) during the experiments. Further research will be necessary to understand the ongoing microbial processes.

\section{Conclusions}

The presented column tests clearly show that even low concentrations of phosphate amendment cause competitive exchange and can enhance biological processes, while higher phosphate dosages suppress microbial activity. Results also indicate that during low amendments of phosphate the microbial reduction of $\mathrm{As}(\mathrm{V})$ occurs very fast and is decoupled from manganese or iron reduction.

Enhanced in-situ arsenic remediation with phosphate bears great potential to accelerate the remediation process considerably. It is suitable for oxic and anoxic redox conditions, as it has no strong effects onto the prevailing redox milieu. Side effects such as mobility of heavy metals were not investigated in this study but have to be considered when applying the method at other places.

Additionally, transport velocities in field applications might be slower due to lower effective porosity of diagenetically compressed sediments in comparison with the manually compacted sediments in the columns. Furthermore, like in all in-situ remediation approaches, the heterogeneities in the sediment profile can change the effect and efficiency of the remediation, which could not be evaluated from the homogenized column material in this study.

Regarding the high phosphate amendment in total, the shares of phosphate consumed during the release processes are very low. Before field application, reactions with excess phosphate have to be considered. In the carbonate-rich aquatic environment of this study, the phosphate is precipitated with calcium, forming mainly white crystalline brushit $\mathrm{CaHPO}_{4} \cdot 2 \mathrm{H}_{2} \mathrm{O}$ (Figures 5 and A5) and shares of hydroxyl apatite $\mathrm{Ca}_{5}\left(\mathrm{PO}_{4}\right)_{3}(\mathrm{OH})$.

In carbonate-dominated systems, co-reactions of phosphate need to be compensated by a higher dosage. An economical application of phosphate is aspired for economic and ecologic reasons. Therefore, an optimal injection technique should be used in order to minimize phosphate amendments for efficient implementation in the remediation practice. Only in the anoxic columns significant amounts of phosphate remained in the sediment matrix after test termination. Future investigations should consider the phosphate precipitation and a potential field application [50].

In order to understand all occurring processes in the aquifer, larger scale studies in the field and geochemical modelling on the phosphate-induced arsenic release should be obtained in the framework of future project cooperation.

Author Contributions: Conceptualization, methodology, formal analysis, investigation, project administration, M.V.M.; methodology, validation and formal analysis, C.S.; supervision: M.I.-S.; writing—original draft preparation and visualization, Y.W. and D.Z.; writing—review, C.N.S.; writing—review and editing, M.V.M. and M.I.-S.

Funding: This work was funded by HIM ASG, Biebesheim and the regional council of Darmstadt (RP Darmstadt). We acknowledge financial support by Deutsche Forschungsgemeinschaft within the funding programme Open Access Publishing, by the Baden-Württemberg Ministry of Science, Research and the Arts and by Ruprecht-Karls-Universität Heidelberg.

Acknowledgments: The authors like to thank all colleagues from the University of Heidelberg, who contributed to the studies with laboratory works and scientific input. We also thank CDM Smith for technical and the Hessian Agency for Nature Conservation, Environment and Geology (HNLUG) for consultant support. Thank you to Amanda Wendt and Susanne Braun for language corrections and the reviewers for the helpful remarks and feedback.

Conflicts of Interest: The authors declare no conflict of interest. The funders had no role in the design of the study; in the collection, analyses or interpretation of data; in the writing of the manuscript or in the decision to publish the results. 


\section{Appendix A}

Table A1. Groundwater composition at the study site.

\begin{tabular}{|c|c|c|c|c|c|c|c|c|c|c|c|}
\hline \multicolumn{12}{|c|}{ Field Parameters } \\
\hline \multirow[t]{2}{*}{ Sample ID } & Sampling Depth & \multicolumn{2}{|c|}{ Temperature } & \multicolumn{2}{|c|}{ Electrical Conductivity } & \multicolumn{2}{|c|}{ pH Value } & \multicolumn{2}{|c|}{ Acid Capacity } & ORP & Dissolved Oxygen \\
\hline & (m bgs) & \multicolumn{2}{|c|}{$\left({ }^{\circ} \mathrm{C}\right)$} & \multicolumn{2}{|c|}{$(\mu \mathrm{S} / \mathrm{cm})$} & \multicolumn{2}{|c|}{$(-)$} & \multicolumn{2}{|c|}{ (mmol) } & $(\mathrm{mV})$ & \\
\hline GWM 29/1 & 7.80 & \multicolumn{2}{|c|}{13.3} & \multicolumn{2}{|c|}{795} & \multicolumn{2}{|c|}{7.34} & \multicolumn{2}{|c|}{4.6} & 149 & 1.1 \\
\hline GWM 29/2 & 15.50 & \multirow{2}{*}{\multicolumn{2}{|c|}{$\begin{array}{l}12.5 \\
13.1\end{array}$}} & \multirow{2}{*}{\multicolumn{2}{|c|}{$\begin{array}{l}617 \\
646\end{array}$}} & \multirow{2}{*}{\multicolumn{2}{|c|}{$\begin{array}{l}7.42 \\
7.39\end{array}$}} & \multicolumn{2}{|c|}{4.1} & 49 & 0.2 \\
\hline GWM 29/3 & 22.50 & & & & & & & \multicolumn{2}{|c|}{4.1} & 117 & 0.8 \\
\hline \multicolumn{12}{|c|}{ Major cations } \\
\hline \multirow[t]{2}{*}{ Sample ID } & Sampling Depth & \multicolumn{2}{|c|}{$\mathrm{Fe}$} & Mn & As & As III & As V & $\mathrm{Ca}$ & K & Mg & $\mathrm{Na}$ \\
\hline & (m bgs) & \multicolumn{2}{|c|}{$(\mathrm{mg} / \mathrm{L})$} & $(\mu \mathrm{g} / \mathrm{L})$ & $(\mu \mathrm{g} / \mathrm{L})$ & $(\mu \mathrm{g} / \mathrm{L})$ & $(\mu \mathrm{g} / \mathrm{L})$ & $(\mathrm{mg} / \mathrm{L})$ & $(\mathrm{mg} / \mathrm{L})$ & $(\mathrm{mg} / \mathrm{L})$ & $(\mathrm{mg} / \mathrm{L})$ \\
\hline GWM 29/1 & 7.80 & \multicolumn{2}{|c|}{2.24} & 407 & 667 & 19.0 & 648 & 154 & 9.46 & 9.74 & 18.9 \\
\hline GWM 29/2 & 15.50 & & & 462 & 322 & 68.1 & 254 & 120 & 6.29 & 8.51 & 12.1 \\
\hline GWM 29/3 & 22.50 & & & 480 & 230 & 26.9 & 203 & 129 & 7.21 & 9.02 & 14.4 \\
\hline & & & & & Heavy $n$ & & & & & & \\
\hline Sample ID & Sampling Depth & Al & $\mathrm{Cd}$ & Co & $\mathrm{Cr}$ & & & $\mathrm{Ni}$ & $\mathrm{Pb}$ & $\mathrm{Sr}$ & $\mathrm{Zn}$ \\
\hline & (m bgs) & $(\mu \mathrm{g} / \mathrm{L})$ & $(\mu \mathrm{g} / \mathrm{L})$ & $(\mu \mathrm{g} / \mathrm{L})$ & $(\mu \mathrm{g} / \mathrm{L})$ & & & $(\mu \mathrm{g} / \mathrm{L})$ & $(\mu \mathrm{g} / \mathrm{L})$ & $(\mu \mathrm{g} / \mathrm{L})$ & $(\mu \mathrm{g} / \mathrm{L})$ \\
\hline GWM 29/1 & 7.80 & $<50$ & $<5$ & $<5$ & $<5$ & & & $<5$ & $<10$ & 244 & 60 \\
\hline GWM 29/2 & 15.50 & $<50$ & $<5$ & $<5$ & $<5$ & & & $<5$ & $<10$ & 258 & 29.6 \\
\hline GWM 29/3 & 22.50 & $<50$ & $<5$ & $<5$ & $<5$ & & & $<5$ & $<10$ & 260 & 33.5 \\
\hline & & & & & Anio & & & & & & \\
\hline Sample ID & Sampling Depth & $\mathrm{NO}_{3}$ & & $\mathrm{SO}_{4}$ & $\mathrm{PO}_{4}$ & & & $\mathrm{Cl}$ & & & \\
\hline & (m bgs) & $(\mathrm{mg} / \mathrm{L})$ & & $(\mathrm{mg} / \mathrm{L})$ & $(\mathrm{mg} / \mathrm{L})$ & & & $(\mathrm{mg} / \mathrm{L})$ & & & \\
\hline GWM 29/1 & 7.80 & 5.4 & & 171 & $<1$ & & & 20.5 & & & \\
\hline GWM 29/2 & 15.50 & 1.1 & & 106 & $<1$ & & & 14.9 & & & \\
\hline GWM 29/3 & 22.50 & 1.2 & & 126 & $<1$ & & & 16.4 & & & \\
\hline & & & & & Carb & & & & & & \\
\hline Sample ID & Sampling Depth & $\mathrm{HCO}_{3}{ }^{-}$ & & TC & TIC & & & & TOC & & \\
\hline & (m bgs) & $(\mathrm{mg} / \mathrm{L})$ & & $(\mathrm{mg} / \mathrm{L})$ & $(\mathrm{mg} / \mathrm{L})$ & & & & $(\mathrm{mg} / \mathrm{L})$ & & \\
\hline GWM 29/1 & 7.80 & 270 & & 58.9 & 53 & & & & 5.87 & & \\
\hline GWM 29/2 & 15.50 & 225 & & 49.7 & 44.2 & & & & 5.51 & & \\
\hline GWM 29/3 & 22.50 & 247 & & 52.3 & 48.5 & & & & 3.75 & & \\
\hline GWM 29/3 & 22.50 & 247 & & 52.3 & 48.5 & & & & 3.75 & & \\
\hline
\end{tabular}


Table A2. Overview of the used measurements methods, ranges and quality control.

\begin{tabular}{|c|c|c|c|}
\hline Method & $\begin{array}{c}\text { Limit of } \\
\text { Determination (As) }\end{array}$ & Reference Material & Standard Deviation \\
\hline & & SPW-SW2 & \\
\hline ICP-OES (water) & $50 \mu \mathrm{g} / \mathrm{L}$ & TMDA 51.3 & $1-15 \%$ \\
\hline HG-ICP-OES (As(III)) & $2.50 \mu \mathrm{g} / \mathrm{L}$ & $\begin{array}{c}3 \times \text { replication of } \\
\text { measurement }\end{array}$ & $1-8 \%$ \\
\hline $\begin{array}{l}\text { ICP-OES (aqua } \\
\text { regia/elutions) }\end{array}$ & $2.50 \mathrm{mg} / \mathrm{kg}$ & BAM U112a, Blank & $2.83-5.35 \%$ \\
\hline Photometer (phosphate) & $0.53 \mathrm{mg} / \mathrm{L}$ & & $6.02 \%$ \\
\hline
\end{tabular}

Table A3. Geochemical characteristics of the aquifer material from the liner (GWM 29) used for the columns, results from aqua regia extractions (n.n. = below detection).

\begin{tabular}{cccccccccc}
\hline \multirow{2}{*}{ Sample } & Depth & $\begin{array}{c}\text { As } \\
\text { Total }\end{array}$ & $\mathbf{C a}$ & $\mathbf{M n}$ & $\mathbf{F e}$ & $\mathbf{C a C O}_{3}$ & Carbonate & C Total & $\begin{array}{c}\mathbf{C}_{\text {org }} \\
\text { (calc.) }\end{array}$ \\
\cline { 2 - 10 } & $\mathbf{( m ~ b g s )}$ & $\mathbf{( m g / k g )}$ & $\mathbf{( \% )}$ & $\mathbf{( m g / k g )}$ & $\mathbf{( \% )}$ & $\mathbf{( \% )}$ & $\mathbf{( a s} \mathbf{\%})$ & $\mathbf{( \% )}$ & $\mathbf{( \% )}$ \\
\hline $29-1+2$ & $1-2$ & 35.2 & 0.56 & 151 & 0.63 & n.n. & n.n. & n.n. & n.n. \\
\hline $29-3$ & 3 & 12.5 & 1.82 & 105 & 0.45 & 4.30 & 0.52 & 0.64 & 0.12 \\
\hline $29-5$ & 5 & 60.5 & 0.72 & 28 & 0.20 & 2.15 & 0.28 & 0.23 & 0 \\
\hline $29-7$ & 7 & 25.8 & 1.86 & 56.2 & 0.27 & 6.46 & 0.78 & 0.96 & 0.18 \\
\hline $29-9$ & 9 & 28.9 & 3.30 & 68.2 & 0.29 & 7.94 & 0.95 & 1.15 & 0.20 \\
\hline $29-11$ & 11 & 33.6 & 2.95 & 85 & 0.41 & 12.2 & 1.47 & 1.36 & 0 \\
\hline $29-13$ & 13 & 22.2 & 2.17 & 59.7 & 0.30 & 7.27 & 0.87 & 0.70 & 0 \\
\hline $29-15$ & 15 & 25.4 & 2.87 & 66.2 & 0.31 & 6.13 & 0.74 & 0.77 & 0.03 \\
\hline
\end{tabular}

Table A4. Composition of the replicated groundwater used for the column tests based on the water composition at the contaminated site.

\begin{tabular}{llll}
\hline Ion & Concentration $(\mathbf{m g} / \mathbf{L})$ & Added as & Source and Quality \\
\hline $\mathrm{Ca}^{2+}$ & 128 & $\mathrm{CaSO}_{4}{ }^{2-} \cdot \mathrm{H}_{2} \mathrm{O}$ and $\mathrm{CaCO}_{3}$ & MERCK/Grüssing (p.a) \\
$\mathrm{Mg}^{2+}$ & 8 & $\mathrm{MgCl}_{2}{ }^{2-} \cdot 6 \mathrm{H}_{2} \mathrm{O}$ & AppliChem (p.a) \\
$\mathrm{Na}^{+}$ & 10 & $\mathrm{NaHCO}_{3}$ & Grüssing (p.a) \\
$\mathrm{K}^{+}$ & 5 & $\mathrm{KHCO}_{3}$ & Theoretikum (p.a) \\
$\mathrm{NO}_{3}{ }^{-}$ & $5^{*}$ & $\mathrm{NaNO}_{3}$ & Grüssing (p.a) \\
$\mathrm{SO}_{4}{ }^{2-}$ & 120 & $\mathrm{CaSO}_{4}{ }^{2+}$ & MERCK (p.a) \\
$\mathrm{Cl}^{-}$ & 23 & $\mathrm{MgCl}_{2}{ }^{2-} \cdot 6 \mathrm{H}_{2} \mathrm{O}$ & AppliChem (p.a) \\
\hline
\end{tabular}

* Only for oxic columns, for anoxic columns: $0 \mathrm{mg} / \mathrm{L}$.

Table A5. Column geometry, redox conditions and phosphate application.

\begin{tabular}{cccccc}
\hline Column & Diameter $(\mathbf{m})$ & Length $(\mathbf{m})$ & $\begin{array}{c}\text { Redox } \\
\text { Condition }\end{array}$ & $\begin{array}{c}\text { Discharge } \\
\text { (L/day) }\end{array}$ & $\begin{array}{c}\text { Phosphate } \\
\text { Application }\end{array}$ \\
\hline 1 & 0.005 & 0.3 & Oxic & 0.18 & none \\
2 & 0.004 & 0.3 & Oxic & 0.22 & via bypass into \\
3 & 0.004 & 0.3 & Oxic & 0.22 & columns entry \\
\hline 4 & 0.005 & 0.3 & Anoxic & 0.18 & none \\
5 & 0.005 & 0.3 & Anoxic & 0.18 & added to process water \\
6 & 0.005 & 0.3 & Anoxic & 0.18 & after degassing \\
\hline
\end{tabular}


Table A6. Considered parameters, applied sample preparation and analytical methods.

\begin{tabular}{|c|c|c|c|}
\hline \multicolumn{4}{|l|}{ Sediment Samples } \\
\hline Aqua regia extraction & $\begin{array}{l}\text { As (tot) and } \\
\text { cations }\end{array}$ & $\begin{array}{l}1 \mathrm{~g} \text { sample with } 3 \mathrm{~mL} 65 \%, \mathrm{HNO}_{3} \\
\text { and } 9 \mathrm{~mL} 37 \% \mathrm{HCl} \text {, filled up to } \\
50 \mathrm{~mL} \text { and filtered through } \\
\text { folded filter }\end{array}$ & \multirow[t]{3}{*}{$\begin{array}{l}\text { (HG)-ICP-OES (VISTA-MPX } \\
\text { CCD Simultaneous; Varian) }\end{array}$} \\
\hline Water elution & $\begin{array}{l}\text { As (III) and As } \\
\text { (tot) }\end{array}$ & $\begin{array}{l}3.5 \mathrm{~g} \text { sample add. } 40 \mathrm{~mL} \text { distilled } \\
\text { water, filtered by } 0.45 \mu \mathrm{m} \text { and } \\
\text { stabilized at } \mathrm{pH} 1 \text { with } 6 \mathrm{M} \mathrm{HCl}\end{array}$ & \\
\hline Phosphate elution & $\begin{array}{l}\text { As (III) and As } \\
\text { (tot) }\end{array}$ & $\begin{array}{l}3.5 \text { g sample add. } 40 \mathrm{~mL} 1 \mathrm{M} \\
\mathrm{NaH}_{2} \mathrm{PO}_{4} \text {, filtered by } 0.45 \mu \mathrm{m} \text { and } \\
\text { stabilized at pH } 1 \text { with } 6 \mathrm{M} \mathrm{HCl}\end{array}$ & \\
\hline Solid sample & $\mathrm{TC}$ & & SC-Analyzer (SC 144R; Leco) \\
\hline \multicolumn{4}{|l|}{ Water Samples } \\
\hline \multirow{4}{*}{$\begin{array}{l}\text { Inflow solution and } \\
\text { column outflow }\end{array}$} & $\begin{array}{l}\text { As (III), As (tot) } \\
\text { and cations }\end{array}$ & stabilized at $\mathrm{pH} 1$ with $6 \mathrm{M} \mathrm{HCl}$ & $\begin{array}{l}\text { (HG)-ICP-OES (VISTA-MPX } \\
\text { CCD Simultaneous; Varian) }\end{array}$ \\
\hline & Anions & & $\begin{array}{l}\text { IC (Dionex DX-120; } \\
\text { ThermoFisher Scientific) }\end{array}$ \\
\hline & $\mathrm{TIC} / \mathrm{TC}$ & & $\begin{array}{l}\text { TOC (TOC-VCSN; } \\
\text { Shimadzu) }\end{array}$ \\
\hline & Phosphate & Molybdenum-blue method & $\begin{array}{l}\text { UV-VIS Spectrophotometer; } \\
\text { (Specord 50; Analytik Jena) }\end{array}$ \\
\hline Tracer test & Bromide & & $\begin{array}{l}\text { Ion selective electrode } \\
\text { (Br 500; WTW); IC } \\
\text { (Dionex DX-120; } \\
\text { ThermoFisher Scientific) }\end{array}$ \\
\hline
\end{tabular}

Table A7. Sulphate balancing from the inflowing (replicated water) and outflowing water.

\begin{tabular}{|c|c|c|c|c|c|}
\hline & \multirow[b]{3}{*}{ Column } & \multicolumn{3}{|c|}{ Average $\mathrm{SO}_{4}(\mathrm{mg} / \mathrm{L})$} & \multirow{3}{*}{$\begin{array}{c}\text { Deviation } \\
\mathrm{SO}_{4}(\%)\end{array}$} \\
\hline & & \multicolumn{2}{|c|}{ Replicated Water } & \multirow{2}{*}{$\begin{array}{l}\text { Column } \\
\text { Outflow }\end{array}$} & \\
\hline & & Planned & Measured * & & \\
\hline 1 & reference oxic & \multirow{6}{*}{120} & 125 & 129 & 3.25 \\
\hline 2 & oxic $+\mathrm{PO}_{4}$ & & \multirow{2}{*}{120} & 111 & -7.72 \\
\hline 3 & oxic $+\mathrm{PO}_{4}$ & & & 115 & -4.71 \\
\hline 4 & reference anoxic & & 120 & 121 & 0.17 \\
\hline 5 & anoxic $+\mathrm{PO}_{4}$ & & \multirow{2}{*}{121} & 113 & -6.89 \\
\hline 6 & anoxic $+\mathrm{PO}_{4}$ & & & 114 & -6.51 \\
\hline
\end{tabular}

${ }^{*}$ Deviations from the planned amount are due to statistical outliers. 


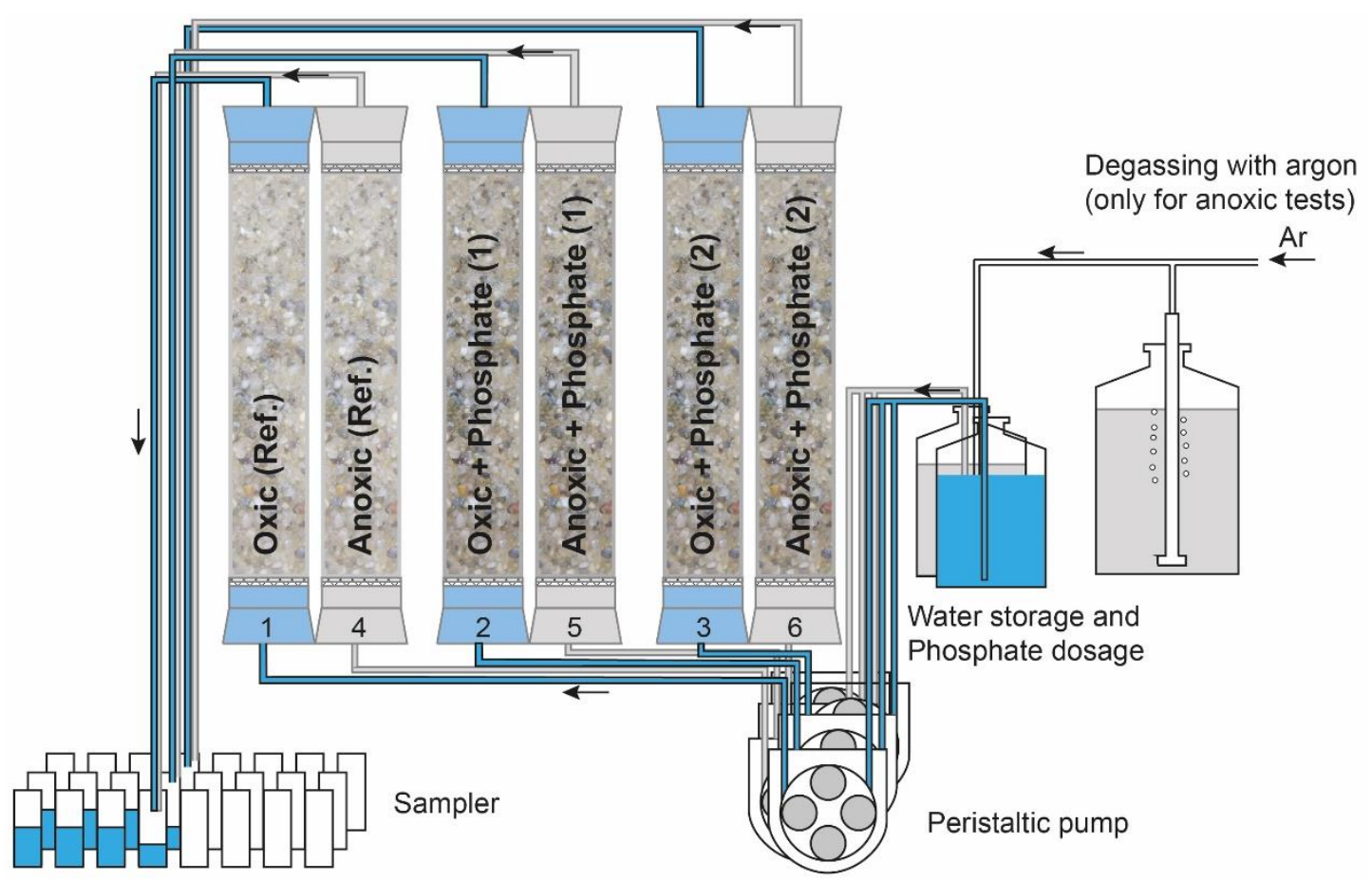

Figure A1. Setup of the column tests. Columns filled with contaminated sediment are percolated from bottom to top by replicated groundwater, to which phosphate is dosed stepwise. For the anoxic tests, the water was degassed with argon before percolation and the whole system was run in an argon floated glove box (modified after [51]). 

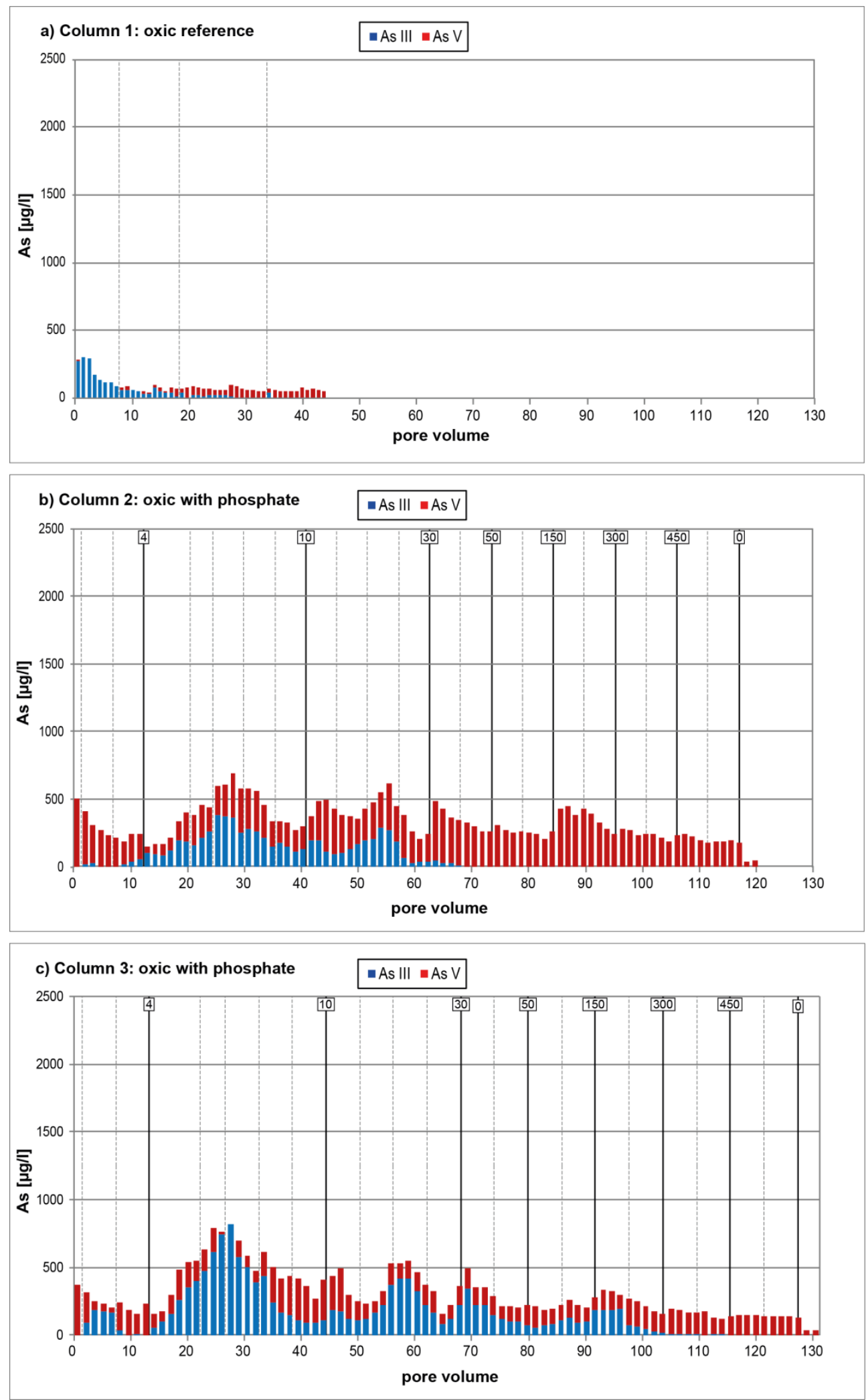

Figure A2. Arsenic release during the oxic column tests, (a) column 1 without phosphate addition and $(\mathbf{b})+(\mathbf{c})$ with phosphate addition in column 2 and 3. Vertical lines indicate refilling of replicated groundwater and the numbers next to them the scheduled phosphate concentration $(\mathrm{mg} / \mathrm{L})$. 
a) Sulphate and bicarbonate of column 2: oxic with phosphate

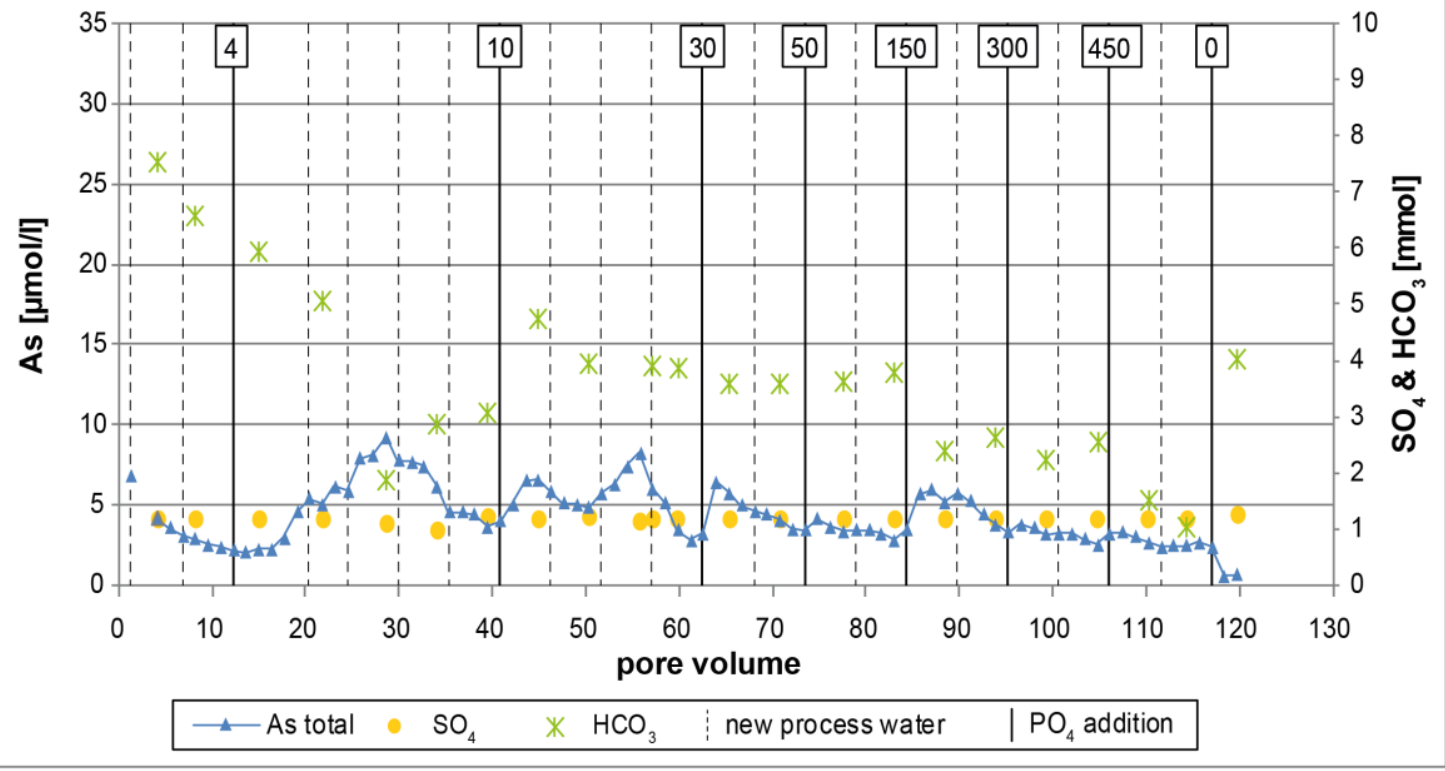

b) Sulphate and bicarbonate of column 5: anoxic with phosphate

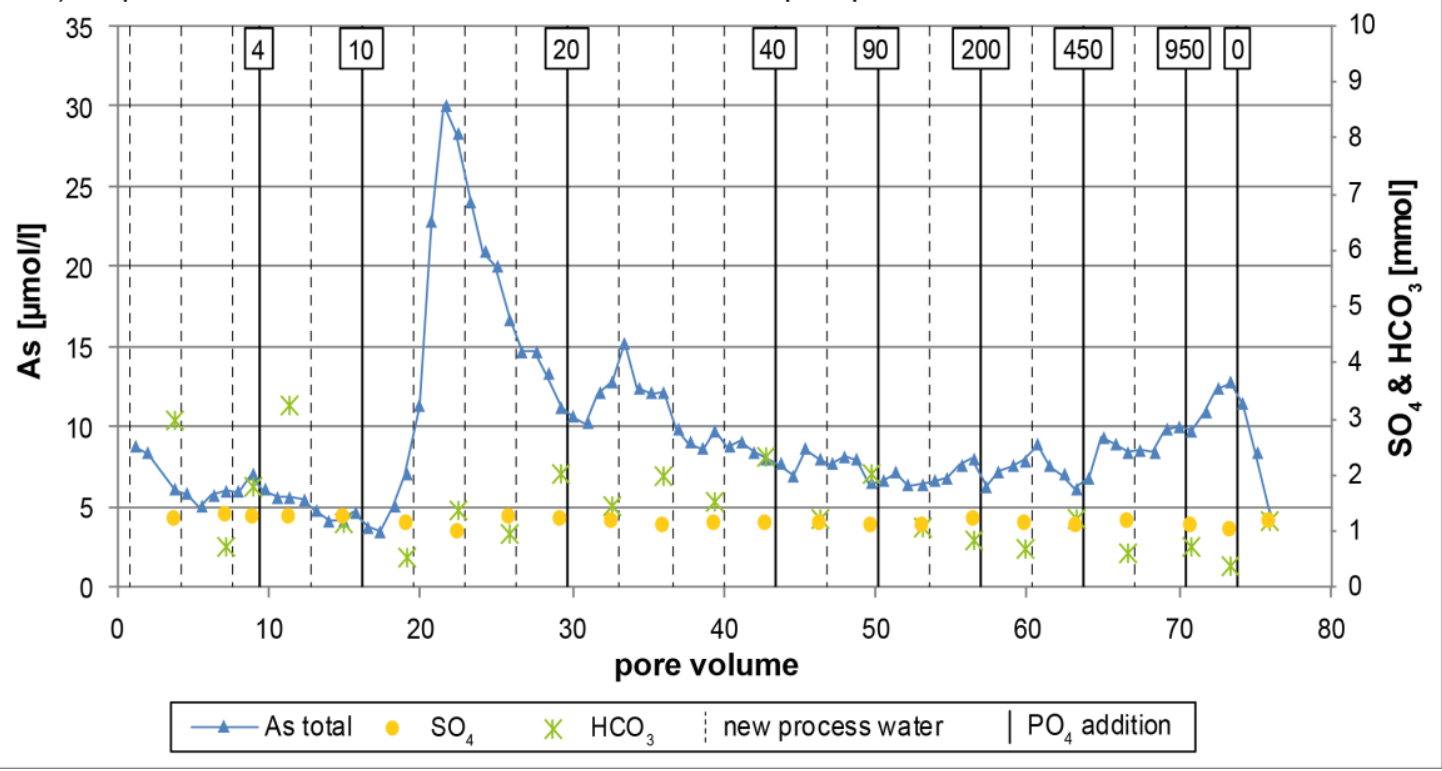

Figure A3. Sulphate $\left(\mathrm{SO}_{4}\right)$ and bicarbonate $\left(\mathrm{HCO}_{3}\right)$ concentrations (right axis) in comparison with arsenic (left axis) in (a) oxic column 2 and (b) anoxic column 5. 

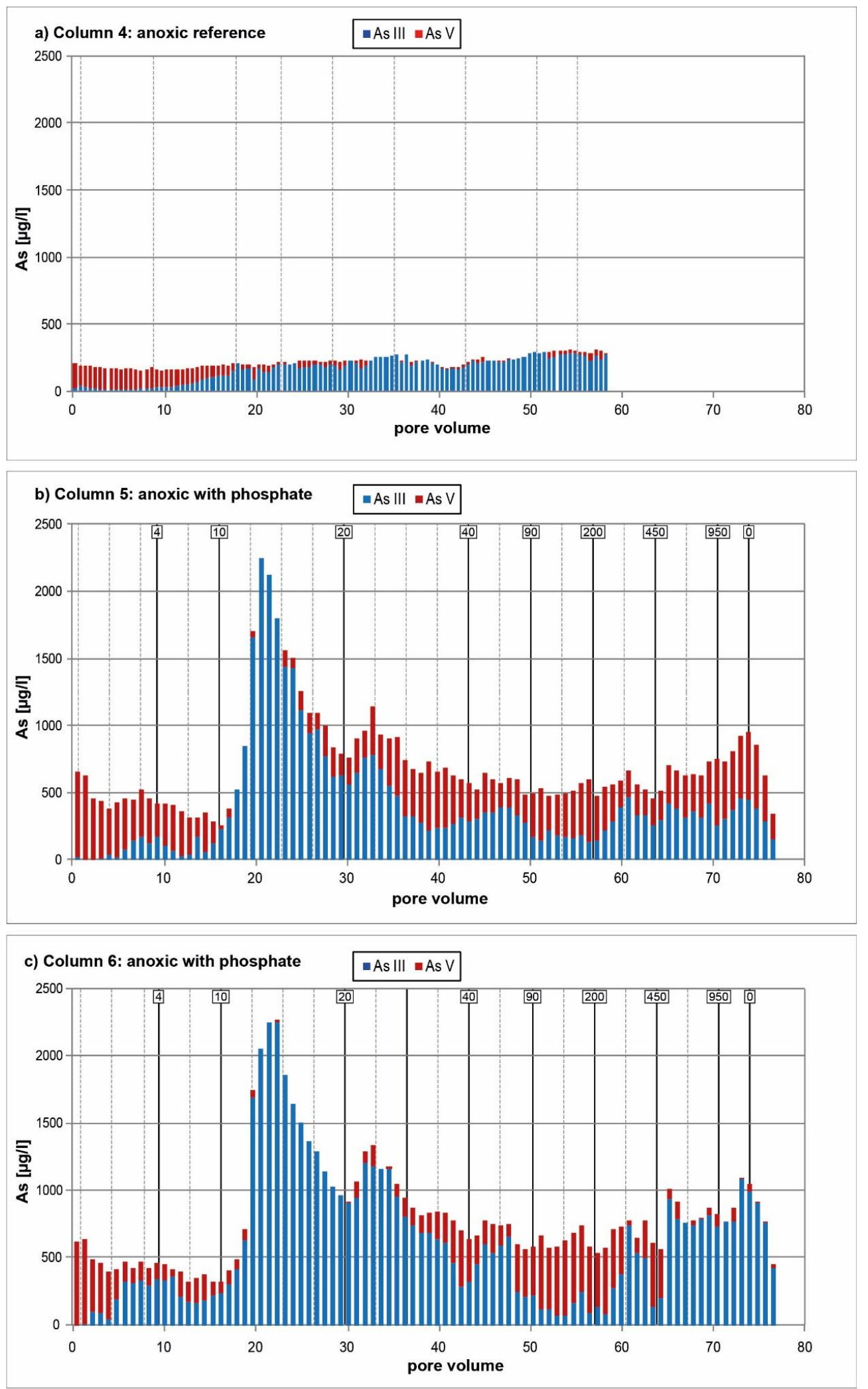

Figure A4. Arsenic release during the anoxic column tests, (a) column 4 without phosphate addition and $(\mathbf{b})+(\mathbf{c})$ column 5 and 6 with phosphate addition. Vertical lines indicate refilling of replicated groundwater, the attached numbers the amended phosphate concentrations $(\mathrm{mg} / \mathrm{L})$ at the time of solution preparation. 


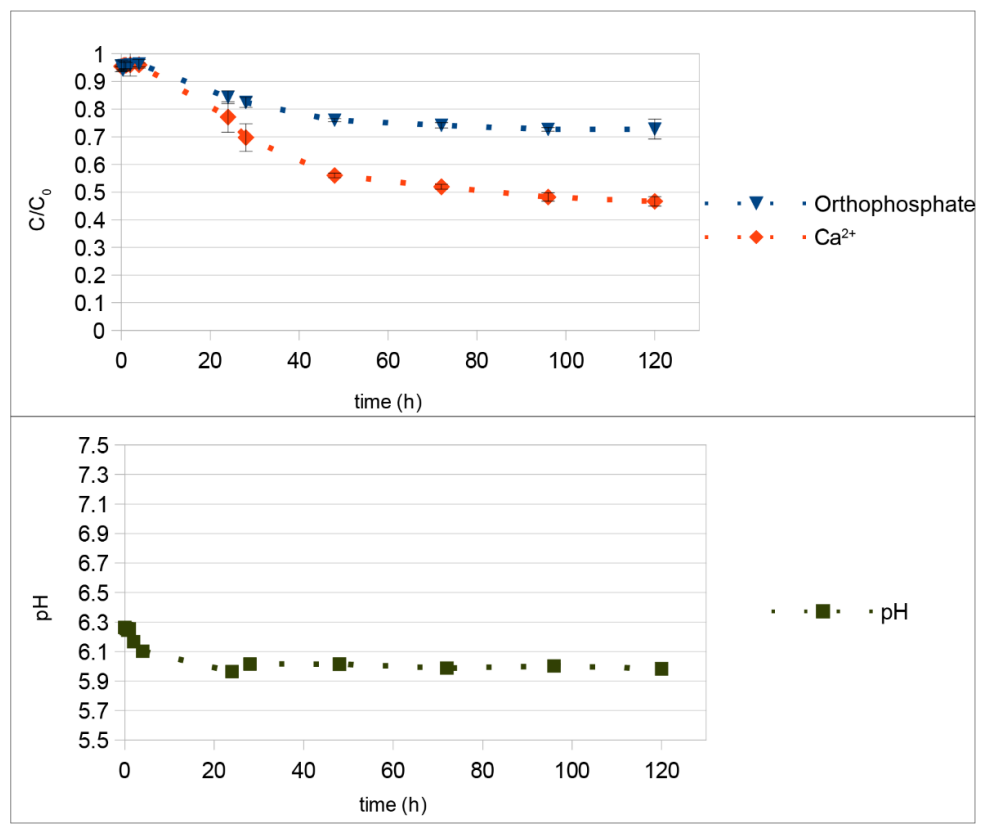

Figure A5. Bottom: Results from a batch experiment with groundwater from the study site verify that even very high phosphate amendments of $10 \mathrm{mmol} / \mathrm{L}$ only result in a small change in $\mathrm{pH}$ value from $\mathrm{pH} 6.3$ to 6 without any further decline. Top: Change in concentration $\left(\mathrm{c} / \mathrm{c}_{0}\right)$ of calcium and orthophosphate over $120 \mathrm{~h}$ show the precipitation of brushit [52].

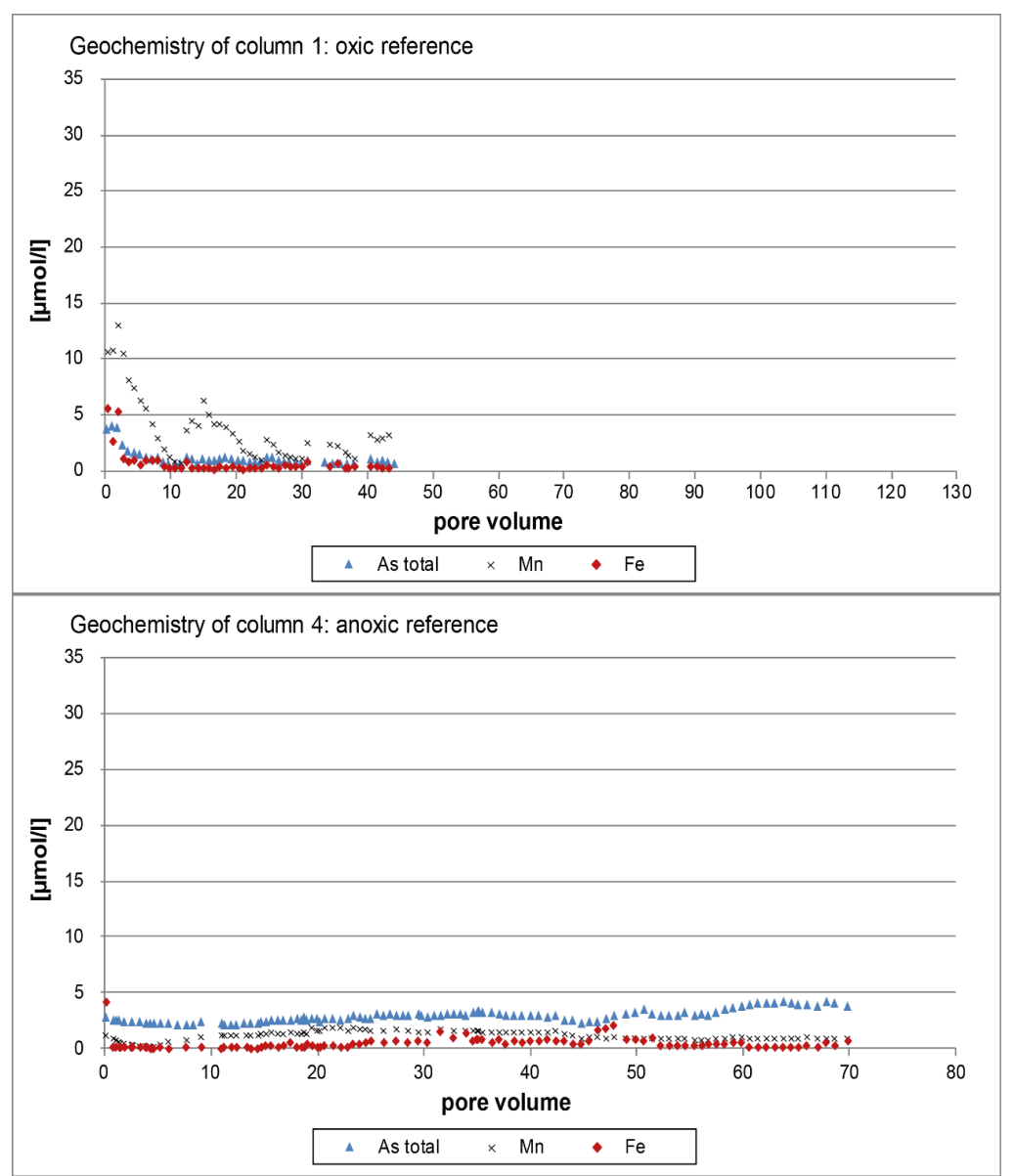

Figure A6. Release of arsenic, manganese and iron in the oxic reference column 1 (top) and the anoxic reference column 4 (bottom). 


\section{References}

1. Eljamal, O.; Sasaki, K.; Tsuruyama, S.; Hirajima, T. Kinetic Model of Arsenic Sorption onto Zero-Valent Iron (ZVI). Water Qual. Expo. Health 2011, 2, 125-132. [CrossRef]

2. Bissen, M.; Frimmel, F.H. Arsenic-A Review. Part II: Oxidation of Arsenic and its Removal in Water Treatment. Acta Hydrochim. Hydrobiol. 2003, 31, 97-107. [CrossRef]

3. Kuhlmeier, P.D. Sorption and desorption of arsenic from sandy soils: Column studies. J. Soil Contam. 1997, 6, 21-36. [CrossRef]

4. Smedley, P.L.; Kinniburgh, D.G. A review of the source, behaviour and distribution of arsenic in natural waters. Appl. Geochem. 2002, 17, 517-568. [CrossRef]

5. Guo, H.; Stüben, D.; Berner, Z.; Yu, Q. Characteristics of arsenic adsorption from aqueous solution: Effect of arsenic species and natural adsorbents. Appl. Geochem. 2009, 24, 657-663. [CrossRef]

6. Bowell, R.J. Sorption of arsenic by iron oxides and oxyhydroxides in soils. Appl. Geochem. 1994, 9, $279-286$. [CrossRef]

7. Dzombak, D.A.; Morel, F.M.M. Surface Complexation Modeling: Hydrous Ferric Oxide; Wiley-Interscience: New York, NY, USA, 1990.

8. Sø, H.U.; Postma, D.; Jakobsen, R.; Larsen, F. Sorption of phosphate onto calcite; results from batch experiments and surface complexation modeling. Geochim. Cosmochim. Acta 2011, 75, 2911-2923. [CrossRef]

9. Biswas, A.; Majumder, S.; Neidhardt, H.; Halder, D.; Bhowmick, S.; Mukherjee-Goswami, A.; Kundu, A.; Saha, D.; Berner, Z.; Chatterjee, D. Groundwater chemistry and redox processes: Depth dependent arsenic release mechanism. Appl. Geochem. 2011, 26, 516-525. [CrossRef]

10. Saunders, J.A.; Lee, M.-K.; Shamsudduha, M.; Dhakal, P.; Uddin, A.; Chowdury, M.T.; Ahmed, K.M. Geochemistry and mineralogy of arsenic in (natural) anaerobic groundwaters. Appl. Geochem. 2008, 23, 3205-3214. [CrossRef]

11. Rochette, E.A.; Bostick, B.C.; Li, G.; Fendorf, S. Kinetics of Arsenate Reduction by Dissolved Sulfide. Environ. Sci. Technol. 2000, 34, 4714-4720. [CrossRef]

12. Bostick, B.C.; Fendorf, S. Arsenite sorption on troilite (FeS) and pyrite (FeS 2$)$. Geochim. Cosmochim. Acta 2003, 67, 909-921. [CrossRef]

13. Bundschuh, J.; Hollander, H.; Lena, M. In-Situ Remediation of Arsenic-Contaminated Sites, 1st ed.; Bundschuh, J., Hollander, H., Lena, M., Eds.; CRC Press, Taylor \& Francis Group: London, UK, 2014.

14. Matthess, G. In Situ Treatment of Arsenic Contaminated Groundwater. In Studies in Environmental Science; Elsevier: Amsterdam, The Netherlands, 1981; Volume 17, pp. 291-296. [CrossRef]

15. Rott, U.; Friedle, M. Eco-friendly and cost-efficient removal of arsenic, iron and manganese by means of subterranean ground-water treatment. Water Supply 2000, 18, 632-636.

16. Kim, M.-J.; Nriagu, J. Oxidation of arsenite in groundwater using ozone and oxygen. Sci. Total Environ. 2000, 247, 71-79. [CrossRef]

17. Krüger, T.; Holländer, H.M.; Stummeyer, J.; Harazim, B.; Boochs, P.-W.; Billib, M. In-situ immobilization of arsenic in the subsurface on an anthropogenic contaminated site. In In-Situ Remediation of Arsenic-Contaminated Sites; Bundschuh, J., Holländer, H.M., Ma, L.Q., Eds.; CRC Press, Taylor \& Francis Group: London, UK, 2014.

18. Luong, V.T.; Cañas Kurz, E.E.; Hellriegel, U.; Luu, T.L.; Hoinkis, J.; Bundschuh, J. Iron-based subsurface arsenic removal technologies by aeration: A review of the current state and future prospects. Water Res. 2018, 133, 110-122. [CrossRef] [PubMed]

19. Onstott, T.C.; Chan, E.; Polizzotto, M.L.; Lanzon, J.; DeFlaun, M.F. Precipitation of arsenic under sulfate reducing conditions and subsequent leaching under aerobic conditions. Appl. Geochem. 2011, 26, 269-285. [CrossRef]

20. Gemeinhardt, C.; Müller, S.; Weigand, H.; Marb, C. Chemical immobilisation of arsenic in contaminated soils using iron(II)sulphate-advantages and pitfalls. Water Air Soil Pollut. Focus 2006, 6, 281-297. [CrossRef]

21. Köber, R.; Daus, B.; Ebert, M.; Mattusch, J.; Welter, E.; Dahmke, A. Compost-Based Permeable Reactive Barriers for the Source Treatment of Arsenic Contaminations in Aquifers: Column Studies and Solid-Phase Investigations. Environ. Sci. Technol. 2005, 39, 7650-7655. [CrossRef] [PubMed]

22. Klaas, N.; Braun, J.; Mackenberg, S. Wissenschaftlicher Bericht Nr. 2007/06 (VEG 23) Entwicklung Eines Immobilisierungsverfahrens für Schwermetalle unter Nutzung des Geogenen Sulfatgehaltes im Grundwasser; VEGAS: Stuttgart, Germany, 2007. 
23. Zeng, H.; Fisher, B.; Giammar, D.E. Individual and Competitive Adsorption of Arsenate and Phosphate to a High-Surface-Area Iron Oxide-Based Sorbent. Environ. Sci. Technol. 2008, 42, 147-152. [CrossRef] [PubMed]

24. Kent, D.B. The influence of groundwater chemistry on arsenic concentrations and speciation in a quartz sand and gravel aquifer. Geochem. Trans. 2004, 5, 1-12. [CrossRef]

25. Hongshao, Z.; Stanforth, R. Competitive Adsorption of Phosphate and Arsenate on Goethite. Environ. Sci. Technol. 2001, 35, 4753-4757. [CrossRef] [PubMed]

26. Luengo, C.; Brigante, M.; Avena, M. Adsorption kinetics of phosphate and arsenate on goethite. A comparative study. J. Colloid Interface Sci. 2007, 311, 354-360. [CrossRef] [PubMed]

27. Manning, B.A.; Goldberg, S. Modeling Competitive Adsorption of Arsenate with Phosphate and Molybdate on Oxide Minerals. Soil Sci. Soc. Am. J. 1996, 60, 121-131. [CrossRef]

28. Bardelli, F.; Benvenuti, M.; Costagliola, P.; Di Benedetto, F.; Lattanzi, P.; Meneghini, C.; Romanelli, M.; Valenzano, L. Arsenic uptake by natural calcite: An XAS study. Geochim. Cosmochim. Acta 2011, 75, 3011-3023. [CrossRef]

29. Yokoyama, Y.; Tanaka, K.; Takahashi, Y. Differences in the immobilization of arsenite and arsenate by calcite. Geochim. Cosmochim. Acta 2012, 91, 202-219. [CrossRef]

30. Sø, H.U.; Postma, D.; Jakobsen, R.; Larsen, F. Sorption and desorption of arsenate and arsenite on calcite. Geochim. Cosmochim. Acta 2008, 72, 5871-5884. [CrossRef]

31. Pigna, M.; Krishnamurti, G.S.R.; Violante, A. Kinetics of Arsenate Sorption-Desorption from Metal Oxides. Soil Sci. Soc. Am. J. 2006, 70, 2017-2027. [CrossRef]

32. Alam, M.G.; Tokunaga, S.; Maekawa, T. Extraction of arsenic in a synthetic arsenic-contaminated soil using phosphate. Chemosphere 2001, 43, 1035-1041. [CrossRef]

33. Woolson, E.A.; Axley, J.H.; Kearney, P.C. The Chemistry and Phytotoxicity of Arsenic in Soils: II. Effects of Time and Phosphorus. Soil Sci. Soc. Am. J. 1973, 37, 254-259. [CrossRef]

34. Wovkulich, K.; Mailloux, B.J.; Lacko, A.; Keimowitz, A.R.; Stute, M.; Simpson, H.J.; Chillrud, S.N. Chemical treatments for mobilizing arsenic from contaminated aquifer solids to accelerate remediation. Appl. Geochem. 2010, 25, 1500-1509. [CrossRef] [PubMed]

35. O’Reilly, S.E.; Strawn, D.G.; Sparks, D.L. Residence Time Effects on Arsenate Adsorption/Desorption Mechanisms on Goethite. Soil Sci. Soc. Am. J. 2001, 65, 67. [CrossRef]

36. Maier, M. Untersuchungen zum Reaktiven Transport von Arsen im Grundwasserleiter: Prozessstudie und Entwicklung Einer Neuartigen Sanierungsmethode an Einem Altstandort in Hessen; Ruprecht-Karls-Universität Heidelberg: Heidelberg, Germany, 2014. [CrossRef]

37. Maier, M.V. Insitu-Mobilisierung von Arsen im Grundwasser. In Handbuch Altlastensanierung und Flächenmanagement (HdA); Franziskus, V., Altenbockum, M., Gerhold, T., Eds.; Hütig Jehle Rehm Verlag: Heidelberg, Germany, 2016; ISBN 978-3-8073-2397-8.

38. Keon, N.E.; Swartz, C.H.; Brabander, D.J.; Harvey, C.; Hemond, H.F. Validation of an arsenic sequential extraction method for evaluating mobility in sediments. Environ. Sci. Technol. 2001, 35, 2778-2784. [CrossRef] [PubMed]

39. Rüde, T.R. Beiträge zur Geochemie des Arsens; Puchelt, H., Ed.; Karlsruher Geochemische Hefte: Karlsruhe, Germany, 1996; Volume 10.

40. Höhn, R.; Isenbeck-Schröter, M.; Kent, D.B.; Davis, J.A.; Jakobsen, R.; Jann, S.; Niedan, V.; Scholz, C.; Stadler, S.; Tretner, A. Tracer test with As(V) under variable redox conditions controlling arsenic transport in the presence of elevated ferrous iron concentrations. J. Contam. Hydrol. 2006, 88, 36-54. [CrossRef] [PubMed]

41. Appelo, C.A.J.; Postma, D. Geochemistry, Groundwater and Pollution, 2nd ed.; CRC Press, Taylor \& Francis Group: Boca Raton, FL, USA; London, UK; New York, NY, USA, 2005.

42. Kinzelbach, W. Numerische Methoden zur Modellierung des Transports von Schadstoffen im Grundwasser; 2. Aufl.; Oldenbourg: München, Germany; Wien, Austria, 1987.

43. Isenbeck-Schröter, M. Transportverhalten von Schwermetallkationen und Oxoanionen-Laborversuche in Säulen und ihre Modellierung; Berichte Nr. 67; Fachbereich Geowissenschaften: Bremen, Germany, 1995.

44. Macur, R.E.; Jackson, C.R.; Botero, L.M.; Mcdermott, T.R.; Inskeep, W.P. Bacterial Populations Associated with the Oxidation and Reduction of Arsenic in an Unsaturated Soil. Environ. Sci. Technol. 2004, 38, $104-111$. [CrossRef] [PubMed] 
45. Campbell, K.M.; Malasarn, D.; Saltikov, C.W.; Newman, D.K.; Hering, J.G. Simultaneous Microbial Reduction of Iron(III) and Arsenic(V) in Suspensions of Hydrous Ferric Oxide. Environ. Sci. Technol. 2006, 40, 5950-5955. [CrossRef] [PubMed]

46. Huang, J.-H.; Voegelin, A.; Pombo, S.A.; Lazzaro, A.; Zeyer, J.; Kretzschmar, R. Influence of Arsenate Adsorption to Ferrihydrite, Goethite, and Boehmite on the Kinetics of Arsenate Reduction by Shewanella putrefaciens strain CN-32. Environ. Sci. Technol. 2011, 45, 7701-7709. [CrossRef] [PubMed]

47. Dhar, R.K.; Zheng, Y.; Saltikov, C.W.; Radloff, K.A.; Mailloux, B.J.; Ahmed, K.M.; van Geen, A. Microbes Enhance Mobility of Arsenic in Pleistocene Aquifer Sand from Bangladesh. Environ. Sci. Technol. 2011, 45, 2648-2654. [CrossRef] [PubMed]

48. Zhang, X.; Jia, Y.; Wang, S.; Pan, R.; Zhang, X. Bacterial reduction and release of adsorbed arsenate on Fe(III)-, Al- and coprecipitated Fe(III)/Al-hydroxides. J. Environ. Sci. 2012, 24, 440-448. [CrossRef]

49. Slaughter, D.C.; Macur, R.E.; Inskeep, W.P. Inhibition of microbial arsenate reduction by phosphate. Microbiol. Res. 2012, 167, 151-156. [CrossRef] [PubMed]

50. Maier, M.V.; Isenbeck-Schröter, M.; Klose, L.B.; Ritter, S.M.; Scholz, C. In situ-mobilization of arsenic in groundwater-an innovative remediation approach? Procedia Earth Planet. Sci. 2017, 17, 452-455. [CrossRef]

51. Tretner, A. Sorptions- und Redoxprozesse von Arsen an Oxidischen Oberflächen-Experimentelle Untersuchungen; Ruprecht-Karls-Universität Heidelberg: Heidelberg, Germany, 2002. [CrossRef]

52. Burger, J. Untersuchungen zur Fällungskinetik von Calciumphosphaten Batchversuche mit Grundwasser; Ruprecht-Karls-University Heidelberg: Heidelberg, Germany, 2014.

(C) 2019 by the authors. Licensee MDPI, Basel, Switzerland. This article is an open access article distributed under the terms and conditions of the Creative Commons Attribution (CC BY) license (http://creativecommons.org/licenses/by/4.0/). 